Breve er saa vardifulde, fordi de opbevarer det umiddelbare $i$ Tilvarelsen

Goethe

\title{
Degn H. M. Toftes Breve fra Flensborg 1864-67
}

\author{
Af H. F. Petersen.
}

En sarlig vigtig og interessunt Periode i Flensborgs og Omegns Historie danner Tiden 186\%-67, vel kun et kort Tidsafsnit, men fuldt af Skuffelser og Forventninger, Tro og Fortvivlelse, Fejghed og Mod, Tiden mellem den tyske Besattelse $i$ 1864 og Afstemningen $i$ 1865.

Ingen kan skildre en saadan Tia saa levende som den, der selv har oplevet den og formaar at fortielle sandt derom. Men $i$ Reglen gaur det jo saaledes, at den, som oplever mest, faar mindst Lyst og Tid til at skrive derom, i Dagbog eller Brove.

Vi er saa heldige at eje en ganske sjelden Skildring af Stemningerne og Tilstandene $i$ Flensborg 186h-6it $i$ en Afskrift af Degn Toftes Breve til de afsatte danske Præster Graae og Vilhelm Munck og gennem dem til daværende Departementschef Kegenburg ${ }^{1}$. De er nasten skrevne Dag for Dag og af Hensyn til Censuren undertegnede med forskellige Navne og Bogstaver.

Det, som kendetegner Brevene, er deres I'dførlighed og Friskhed. Sproget er djærvt og naturligt, Skildringen uden Omsvøb og lange Betragtninger, Indholdet er hum $\phi$ rfyldt og dog fuldt af Alvor.

En del af degn Toftes breve har tidligere varet offentliggjort, jvfr. H. F. Petersen: Danske i Sydslesvig, 1933 side 42 ff. og Kirkeligt samfunds julebog 1932 side 143-163. I betragtning af det interessante tidsbillede og de værdifulde bidrag til en karakteristik af degn Tofte, som brevuddragene giver, har man gerne her villet samle de spredte tidligere trykte breve med de hidtil utrykte.

1) I Rigsarkivet: Regenburgs Samlinger $\mathrm{S}$.

Red. 
Hans Wikkelsen Tofte var fodt den 13. December 1825 i Tirslund Skole, Haderslev Amt. Hans Far, Jens Tofte, liom fra Toftlund ${ }^{2}$ ), hvorfra ogsaa Fumilienavnet Toft, som Sønnen fik ved Daaben, stammede. Fadercn var egentlig Snedker og Murer, men var Larer om vinteren, hoad Tiden nøjedes med. Moderen hed Maren Hansdatter Lykke og var fra Vesterlinnet $i$ Gram Sogn'). Hendes Far hed Hans Mikkelsen.

Allerede som Barn og ung war Tofte $i$ Besiddelse af en naturlig Livsglade, en varm Fsedrelandskarlighed og en alvorlig Gudsfrygt. Fra Moderen havde han arvet en stærk Virksomhedstrang og en udmarket Sangstemmi. Ligesom Broderen Hans Christion. der blev Laerer $i$ Vildbjerg ved Herning og senere i Hornstrup ved Vejle, slog Hans Mikkelsen Tofte ind paa Larervejen. 1846 dimitteredes han fra Lyngby Seminarium paa Djursland og kom sut som Andenlarer til Skarbak.

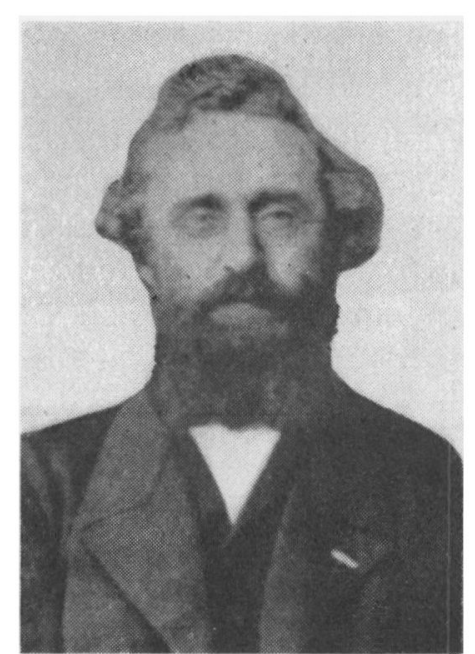

Hans Mikkelsen Tofte ved afskeden fra Flensbory.

Dagen efter Kampen ved Brons den 22. Januar 1849 samlede han sine Skolebørn og fortalte dem om Begivenheden: Der var blevet kampet, og mange var faldne; men - sluttede han skal vi saa ikke synge »Vor Gud han er sau fast en Borg«. Mange dar senere mindedes man endnu Larerens iltre Harme og smittende Harb.

Efter Treaarskrigen var det Flensborg, der kaldte. Her var det Meningen at vakke den slumrende Danskhed op af Dvale, og hertil behфvedes frem for alt en dygtig Præst og en Lærer, som tillige kunde være Degn ved den danske Kirke.

Der var mange Ansфgere til begge Pionerstillinger; kaldede

2) Sprogforeningens Almanak for 1924, S. 56 ff.

3) Dansk biografisk Leksikon XXIV, S. $161 \mathrm{f}$. 
blev G. Fr. A. Graae som Præst og Hans Mikkelsen Tofte som Legn.

Fra Pastor Graae modtog den nye Degn følgende hjertelige Linjer:

»Højstærede, kjare Hr. Tofte!

Da jeg haaber, at vi snarest samles for at virke i Forening som tro Medarbejdere, vil jeg med disse Linier alene underrette Dem om, at jeg, efter Deres Yttring i Deres Brev af 17de dennes, gjør Regning paa, at De vil, med Guds Hjælp! kunne blive indsat Søndagen den 9de Novbr., hvilket jeg derfor lader bekjendtsjøre et Par Dage iforveien i Avisen. S $\phi$ ndagen iforveien havde jeg nok фnsket at have Dem her, da her er Konfirmation; men jeg kan nok tænke, at De har adskillige Sager at bringe i Rigtighed f $\varnothing$ rst. Vor Herre vare nu med Dem, og lade Deres Gjerning lykkes godt for Dem!

Deres hengivne Fr. Graae

E.Skr. Efter den lagte Plan, som er indsendt til Ministeriet, skulde Skolen, om muligt, aabnes efter Nytaar; men strax ved Deres Ankomst vil De faae Leilighed til at give Timer i Frøknerne Mylius's Institut, der фnskede en dansk Lærer. - Om Skoleplanen vil De erfare det nærmere ved Deres Ankomst hertil.\&

Den danske Menigheds Borgerskole aabnedes dog først den 9. Januar 1852 med Degn Tofte som Leder og med 27 Børn. Elevantallet voksede fra Aar til Aar og var ved Krigsudbruddet $186 /$ ca. 530 med 8 faste Lærere med en ordineret Kateket, Pastor Vilh. Munck som Førstelærer.

Tofte var som skabt til at opdyrke ny Jord, og at han rigtig følte sig $i$ sit Es, viser efterfølgende Brev til hans ovennæunte Broder).

๑) Efter Pastor Knudsens Afskrift. 
»Nygade Nr. 426 i Flensborg, d. 21. Decbr. 1852.

Kjære Broer!

Du har suamænd ærligen fortjent et Brev, siden Du har skrevet to, mens jeg kun har skrevet eet. Idag fik jeg Ferie, at skrive dette Brev er min f $\phi$ rste Ferie-Gjerning; er Du saa tilfreds?

Har Du faaet et Brev fra mig, siden jeg er kommen hertil? Jeg troer det ikke; derfor vil jeg saa nøie som muligt skildre Dig min Tilstand. Degn og Lærer ,ved den frie danske Menighed”, som først ifjor samlede sig, og som nu udgjør et eget Sogn med Præst og Kateket, Degn og Lærere o.s.v. Enhver, der har Lyst, kan træde ud af en anden Menighed og ind $i$ vor; derfor hedder denne ,den frie".

Hele Noblessen møder hos os, og det vil ikke sige saa lidt $i$ en By med 18000 Indvaanere; det er jo ogsaa Sønderjyllands Hovedstad og har som saadan en Masse Embedsmand, der niesten uden Undtagelse hører til vor Menighed. Vor Menighed er omtrent saa stor som Skærbæks. Min Løn er som Degn af Statskassen 500 Mark Cour. aarlig; saa giver det ogsaa Offer, iaar dog kun en $100 \mathrm{Mk}$., men det bliver nok bedre med Tiden. Vort Samfund voxer, altsaa - gjør selv Slutningen:

Som Lærer ved Skolen har jeg 300 Mk. C. aarlig. Der ser Du mine Indtægter og min Virksomhed. Det værste er, at jeg endnu ikke har faaet fri Bolig, men den kommer vel, naar vi faae en egen Skolebygning. Lokalet til Skolen maae vi ogsaa selv leie. Vort Elevantal er 60 + nogen, deelt i 3 Classer under 3 Lærere, der undervise Fagviis gjennem hele Skolen.

Jeg har Sang gjennem alle Classerne, Regning, Mathematik og Geometri, Naturhistorie, Dansk i nederste Classe. De andre Lærere dele de фvrige Fag. Desforuden er jeg Sanglærer ved den latinske Skole her og har derfor 240 Mk. C. aarlig. NB. Det er privatim: alligevel er det en kjærkommen Fortjeneste, der er passende at stoppe i Halsen paa nogen af de Hrr. Rykkere.

Iaar har jeg havt mange Udgifter, men kan dog nok klare dem nu, hvilket ikke vilde været Tilfældet, naar jeg havde giftet mig. Leilighed og Levemaade ere her satanisk dyre, og skjøndt jeg indskrænker mig saa meget muligt, kan jeg dog anslaae disse til 400 Mk. aarlig. 
Inte gift, ingen Fadderstads, Behageligheder og Ubehageligheder? Som du vil se, altid Perle-Hum $\phi r$. Isommers skrev jeg til min Kjærest("), om hun vilde med mig til Dig en 14 Dage i Ferien; men hun havde ingen Lyst, hvorfor vi, som Du vel kan tænke, ikke kom, og af hvilken Aarsag jeg i denne Tid bes $\emptyset$ gte min kjære Pastor Koch i Skærbæk og levede bon.

Du vil endnu have draget den Slutning, at jeg endnu er i Isesiddelse af mit gode unge Humør, hvorfor jeg ikke behøver at sige Dig, at Fremtiden, med een eneste Undtagelse, maler sig for mig i Haabets smukkeste Grønt, os at — Du skal imidlertid have mange Tak for Din Bekymring for mig - Du med Hensyn til min Tilstand kan vare ganske rolig: jeg lever vel.

Det er for Resten et eget Liv i en Kjøbstad, hvilket i Begyndelsen faldt mig lidt svart; men man vanner sig snart dertil. Din herlige Kone sendes de kjarligste Hilsener; forleden aften sang jeg efter hendes Noder: »I)r boed en Kjæmpe o.s.v.

Jeg er en lidenskabelig Elsker af Musik og Sang.

Din Hans.

Gladelig Juul oğ Nytaar til Eder Alle! Jeg har to Gange Gudstjeneste hver Helligdag, det er vel strengt.«

Livet indenfor dansk Kirke og Skole i Flensborg i Tiden 1851-64 kan ikke udførligt skildres her; det er gjort andensteds'). Men saa meget kan siges, at Tofte фvede en stor Indsats og vandt især Bфrnenes og den javne Mands Hjerter. 18.37 modtog han, kun 32 Aar gammel, Dannebrogsmændenes Hæderstegn af Kong Frederik VII's egen Haand, og af de danske Præster fik han megen Paaskonnelse.

Pastor Vilh e l m M u c k beretter om sit forste Indtryk af Tofte ved sin Overtagelse af Forstelærerstillingen $i$ 1862.?) Mit

5) Først 9. Nov. 1853 stod Brylluppet i Hammelev med Helena Margretha Bertelsen, en Lærerdatter fra Djernæs ved Hoptrup.

b) H. F. Petersen: „Danske i Sydslesvig (1933), S. 26-40; „Flensborg Bys Historie II (1955), S. 206-11; se endvidere S. 211-17 (Åge Bonde).

7) Fængselspræsten Pastor Vilhelm Muncks Optegnelser * $\mathrm{i}$ ^Memoirer og Breve (ved Clausen og Rist) XXXVI (1922), S. 68. 
første Besøg i Skolen gjaldt den udmwrkede Degn og Andenlarer, Tofte. Jeg traf ham i en Klasse med ca. 100 sma Drenge og Piger, der summede som Bier. Jeg blev forbavset staaende ved Døren, og da Tofte gik hen til mig fra Katederet, gik det løs med en saadan Snakken, at der næppe kunde høres Ørenlyd. Det lod ikke til, at dette anfægtede 'Tofte, medens jeg i mit stille Sind kaldte det en uforsvarlig Uorden. Saa vender Tofte sig pludselig mod Bornene og siger: „Duk!” I samme Nu laa alle de smaa Hoveder paa Skolebordene, og der blev fuldstændig stille et Minut eller to. Dette syntes mig et prdagogisk Mesterstykke, naar man skal læse med 100 Børn paa én Gang, og Klassen talte $\mathrm{i}$ Virkeligheden 120 , saa overfyldt var Skolen ved min Ansæettelse, navnlig med smaa Børn.«

Toftes Degnebolig blev fra 185 4 den gamle danske Prastebolig i Helligaandsgangen, vest for og umiddelbart op til Helligaundskirken. Tofte indrettede et af Rummene til Bogsamling, Begyndelsen til den senere Bogsamling paa $\gg$ Margrethes Minde og senere »Flensborghus«. Da det trak op til Krigen 1864, indrettede han ogsaa et Depot for Uldsager til Soldaterne.

Under selve Krigen gjorde Tofte et stort Arbejde blandt de sanrede Soldater og Fanger, som var anbragt $i$ Kirkerne, i Skolerne og alle offentlige Lokaler. „Den store Dansesal „Kolosseum” var fyldt med Senge, baade paa Gulvet og Galleriet «, skriver Munk*), »Det første Syn, der mфdte mig, da jeg kom ind, var en døende aansk Soldat, som endnu i U'niform laa par et Par Stole. Tofte sad b申jet over hans ligblege Ansigt med Gret til hans Mund og med Papir og Blyant $i$ Haanden for at opfange den Doendes sidste Hilsen til hans Kare $i$ Hemmet.

Den 20. August 1864 afskedigedes begge de danske Praster, og den 12. September forlod de Flensborg. Det Afsnit i Pastor Graaes Erindringer, hvori der fortalls om Toftes Virksomhed og tilsidst om Przesternes Afsked med de danske Flensborgere paa Dampskibsbroen, slutter med Ordene: »Men vor gode Ven Tofte var ikke deriblandt. Han vilde ikke staa der og græde som

s) Munck anf. værk S. 86 . 
i Kirken [ved Afskedsgudstjensten]: han var paa Skolen; der var hans Plads, - nu en Kampplads, hvor det gjaldt om at stride en god Strid, og han var nu den, der skulde fore an «. ${ }^{\circ}$ )

Venskabet mellem Tofte og Præsterne fortsattes efter Adskillelsen gennem Korrespondancen, og det er denne fra Aarene 1864-67, som aftrykkes nedenfor. Det har været nфdvendigt at skære en Smule fra og modernisere Retskrivningen. Men Fortællemaaden er bibeholdt, ogsaa der, hvor den kan virke lidt for bramfri. G. og M. efter Datoerne betyder, at Brevet er til Graae,

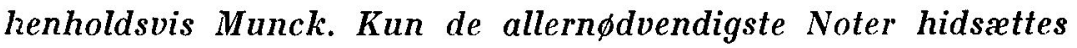
for ikke at besvære Toftes egen Fremstilling. Min Hensigt har været at offentliggфre en Kilde til Belysning af Tidsrummet. At udnytte den, overlader jeg til andre.

Omkring 15. 9. 1864 (G.): Tak for Piben og for alt godt! Alt er nu фde og tomt, men Mod og Haab vokser hos mig og hos alle Slesvigere. Selv flere Slesvig-Holstenere er omvendte, og flere vil vel blive det, naar Kniben bliver større. Eksempler derpaa h $\varnothing$ rte jeg flere af i Harreslev, hvor jeg har været i Eftermiddags. "Gid vi bare maatte komme til at stemme! dette er næsten hver Mands Ønske. Tænk, selv i Svabsted skriver man Adresser til Kongen. Landmaaler Johannsen, der fortalte det $\mathrm{i} W$., gjorde rigtignok Nar deraf, men saa er det vel dog sandt.

Om os er der intet at fortælle, derfor maa De tage til Takke med lidt andet Steds fra. I Harreslev var den elskværdige Præst ${ }^{10}$ ) ovre i Gaar for at visitere Skolen, der jo nu gaar paa Tysk. Almindeligt Spørgsmaal af Præsten: »Sig mig B $\phi \mathbf{r n}$, hvor mange taler Tysk hjemme? " To rejste sig op: de talte Tysk hjemme, det var to Flensborgere. Læreren katekiserede paa Tysk, men Børnene svarede naturligvis ikke til Præstens Forventninger, hvorfor han selv gav sig til at spørge. Blandt andre Spørgsmaal,

9) G. Fr. A. Graae: „Mellem Krigene (1887), S. 67.

10) Præst i Hanved fra 23. 6. 1864 Simon Gerstenkorn Simonsen, f $ø$ dt i Haderslev 1815, 1837-51 Præst i Hjoldelund, lod sig pensionere, da Sprogreskriptet indf $\varnothing$ rte blandet Kirkesprog, 1855 Præst i Lunden, 1861 tillige Provst, virkede i Hanved til 1874. 
der ikke blev besvaret, var ogsaa dette: »Hvor mange Herreder er der i Flensborg Amt? « Det vidste de ikke, ligesom saa meget andet, da Børnene ikke forstod ham. Derover blev den lille Mand gal, ravgal, og Skolen og Læreren fik det glatte Lag, hvilket han tog uden at forandre en Mine, indtil en Kone fra Byen, som stod som Tilhører ved Døren, sagde til Læreren: »Smid dog den Ka'l ud a $æ$ Skoel, Skolmester!«, saa maatte han smile deraf. Fn stor Dreng, der sad langt nede, kunde ikke laese. Præsten bliver vred: „Hvad, kan du ikke læse?« Drengen svarer ikke; han forstaar ham ikke, derfor maa han tale Dansk: »Hvor er du fra?« »E er fra Hanvei«. - En Dreng, der skrev omtrent rigtig Tysk, sagde Præsten til: »Men du taler vel ogsaa Tysk hjemme? « »Nej, æ snakker Dansk hjemme.»

Saadan endte denne Prøve af Læreren, der, som man vel kunde vide, efter denne Behandling af en Tysker som Simonsen, er dansk og fik sin Lektie i Skolen, men hvad Præsten fik derovre i Lærerens egen Stue, derom taler Historien ikke. Jeg tænker, han fik det glatte Lag (det fik han!), men Læreren vil naturligvis blive entlassen [afskediget], og én »vom verlassenen Bruderstamm « ${ }^{11}$ ) komme i hans Sted. Den stakkels gesinnungstüchtige $^{12}$ ) Degn Andersen i Hanved fik ogsaa sit Fedt, men han maatte staa, som om han haldte Vand af Ørene : galt var det med Pastor Friis ${ }^{13}$ ), men varre er det dog at hlive hundset af sine egne! Som man reder, saa ligger man : stakkels Degn maa taale alt; tysk er han, og til Danmark kan han ikke rømme.

Mellem os, skriver ellers Landmaaler Johannsen Noderne med Hensyn til Harreslev, og Presten synger dem. Det er dog rart med denne ene Slesvig-Holstener i Harreslev, det er saa omtrent den eneste, der bes $\varnothing$ ger Gudstjenesten fra denne By. Skolelæereren havde jeg givet nogle Smaaskrifter; de Iaa i hans Storstue i Vinduet, фverst »Jakobs Gud er vor faste Borg«. Om

11) Saaledes hed en Samling antidanske og uvederhæftige Beretninger af Gustav Rasch (I-III, Glogau 1863)

12) 0 : slesvig-holstensksindede.

13) Den afskedigede dansksindede Præst i Hanved, kendt fra Dattersønnen, Kai Friis Møllers Digt sHanved $\mathrm{i}$ „Digte 1908-48* (1948), S. $130 \mathrm{f}$. 
Morgenen, da Præsten tager Frakken af, opdager han Bunken, faar Prædikenen i Haanden, men slænger den vredt til Side, da han havde last Titelbladet. Det var ikke saa sært, det blev Tordenvejr den Dag i Skolen : han (Læreren) havde med Flid lagt Deres Pradiken $\phi$ verst.

I Gaar var ( i Dag er det Onsdag, og jeg begyndte Brevet i Aftes) der en Deputation fra Nordslesvig hos Civilkommissærerne med en Adresse om at blive ved Danmark ${ }^{14}$ ). Den skal tælle ca. $3800\left(\right.$ Underskrifter" $\left.{ }^{16}\right)$. Kammerraad $J_{u h l}$ var nok Anfórer. I Dag modte jeg Madam Mohnsen ${ }^{16}$ ) med slesvig-holstensk Baand om Halsen; jeg tog Hatten meget dybt af for hende. Endnu er vi ikke slagtede, men Slagteren vil snart g $\phi$ re sin Indslagtning for mange Tider : den danske Menighed er Slagtekvæget, og Provst Peters er og kaldes almindelig Slagteren. Klaus (irumtoft ${ }^{17}$ ) har ikke ladet sig se.

23. 9. 186/4 (M.): Skolen gaar sin vante Gang. Hänisch har udmeldt sin lille Dreng efter Provst Peters Raad til den tyske Skole. Vi g $\phi \mathbf{r}$ alt for at faa Skolen i Graven i det mindste og snart, men endnu intet Tegn til Rømning, sk $\phi n t$ Zedlit $z^{18}$ ) har givet godt Haab.

- - Adressen talte 6000 Underskrifter. Zedlitz modtog dem, idet han sagde, om de ikke vidste, at han havde Ret til at kaste dem i Hullet, men fik til Svar: da det andet Parti har Iov til at s $\phi$ re, hvad det vil, saa antager vi, at vi har samme Ret. Det endte med, at $Z$. blev meget natig og lovede at indsende Adressen til sine respektive Regeringer $\left.{ }^{18}\right)$. Saa forlangte de ogsaa Frihed for de indstukne [arresterede? Nordslesvigere, hvilket han ogsaa

14) Jfr. M. Mackeprang: >Nordslesvig 1864-1909 (1910), S. 7.

15) I Randen: NB. Det er nok kun 6000 \%.

18) Gift med en Lærer ved den danske Borgerskole, som var den eneste, som ikke var med paa Afskedsbilledet til Pastor Munck; se dennes Boy S. 94.

17) Den designerede danske, men tysksindede Prast Georg Karstens, Lærers $\varnothing$ fra Grumtofte.

18) Den preussiske Civilkommissær von Zedlitz.

iH) Landet styredes af Preussen og Østrig i Forening. 
lovede - og holdt. Forresten haaber jeg, at, da vor jyske Natur er kommen i Bevægelse, saa vil det i Langden ikke blive ved Adresser, men komme til Haandgribeligheder med det første. Et Par Ben i Stykker paa en Prest eller Gendarm kan vel nok ventes.

Skolebes $\varnothing$ get godt : 63 i Dag i min Klasse, over 90 i Dag i Werners, i det hele godt Bes $\phi g$. Grumtoft ${ }^{20}$ ) har allerede været her siden i Mandags, men jeg har ikke hørt fra ham endnu. Set et Glimt af ham har jeg, men kun paa Afstand. Han bor nok i de to Stuer paa første Sal i Deres Bolig i Graven"1). Jeg vil ikke gøre ham min Opvartning; han vil formodentlig heller ikke først komme til mig : det lader til at blive intimt mellem os. Michrel$\operatorname{sen}^{22}$ ) siger forresten, han er dansk. Mir einerlei. [Mig er det lige fedt!]

Menigheden bestaar endnu. Jeg har i de sidste Dage modtaget 2 Indmeldelser deri. Skulde de vare saa dummc at lade Menigheden bestaa, saa vil jeg fortælle dem, at den vil vokse $i$ høj Grad; jeg har allerede set flere Tesn dertil. Det er et underligt Folkefærd, de Danske her : de vil saa gaa ind i Menigheden for at hjælpe paa vore Finanser.

At vi ses igen her, det har jeg aldrig tvivlet paa; det vil nok ske, men naar? Vorherre ved nok, hvad han gør. Maaske er det godt for gamle Danmark, at det varer noget endnu. - En Mærkelighed er det, at Graaes og Deres første Brev fulgtes ad:

28. 9. 186/ ( G.): Endnu staar alt ved det gamle : Skolen gaar sin vante Gang, og Kirken er taalelig besøgt. Klaus har indlogeret sig i Muncks Lejlighed. Det forekommer mig, at jeg har sunget med ham paa Latinskolen i en Tid, men ved dog ikke, om det er sandt. I Lordags blev der sagt fra Prædikestolen, at den nye

20) Pastor Karstens.

21) Gadenavn i Flensborg.

2:2) Den senere kendte Præst i Uge, Bjolderup og R $\emptyset$ dding, J $\emptyset r g e n$ Michaelsen, var født 28. 1. 1830 i Kastvraa, Uge Sogn, og fra 1862 Lærer ved Flensborg Latinskole. Straks efter Invasionen i 1864 oprettede han Holdts senere danske Privatskole. 
Pastor Carstens ${ }^{25}$ ) vilde holde sin Tiltrædelsespræediken. Han var som Tilh $\phi r e r$ i Kirken, og efter hans Blik at d $\phi$ mme, vilde han der komme nemt fra det og budt mig Goddag, men jeg gjorde en snild Manфvre efter Salmebogen over paa Bænken, og siden var jeg hos Organisten og talte med ham, saa Klaus maa komme ned til mig, hvisomensindenstid han vil have mig fat. Inden Søndag maa han da vist ville tale med Degnen, hvis vi ikke f $\phi$ rste Gang skal mødes i Kirken. Det lader ikke til, at Skolerne vil blive os udleverede, man vil pine os fra hinanden indirekte, andet kan jeg ikke faa ud deraf, da det jo dog ikke kan være nødvendigt at have Skoler til Pakhuse. De andre Skoler er rensede og tagne i Brug. Provst Peters har sørget for, at dette er sket med Marieskolerne. Kan et dansk Blad ikke tage sig af Sagen og vise det smukke ved denne Ting? Vi har endnu $4 \frac{1}{2}$ Hundrede i Skolerne. Hvad Aviserne har talt om den danske Kirkes Brug til fast katolsk Kirke, er ikke sandt: »daran ist kein wahres Wort«, sagde den katolske Præst til mig i Fredags.

Apotheker Zedeler som Formand har indgivet Ans $\varnothing$ gning om, at vi maatte bestaa ligesom St. Petri tyske Menighed i København, og vedf $\varnothing$ jet en Skrivelse fra en af Menighedsforstanderne dersteds. Hvad Lykke denne Gesuch [Ans $\varnothing$ gning] vil faa, faar vi se. Skriv et Raad e. I. om, hvad De mener, vi skal gøre m. H. t. Skolerne! Læreren fra Harreslev var hos Peters i Lørdags og fik en Mængde Spørgsmaal at besvare; han gaar af en af Dagene; han fra Jørgensby er allerede i København.

2. 10. 1864 (G.): En yderst mærkværdig 2. Oktober : Præst og Degn mødes første Gang i Kirken i det lille Aflukke. Degnen kiggede ind. Præsten spurgte: »Maa jeg spørge : er De Hr. Tofte? « Ja, og Degn ved den danske Kirke.« Kiggede paa Kjolen. Degnen spфrger: »Maa jeg sp $\phi$ rge : er De maaske den Præst, der skal være her ved Menigheden? « Ja« — og saa flov ud. Jeg holdt mig stiv, vilde ikke bes $\emptyset$ ge Manden f $\phi \mathrm{r}$ han mig.

${ }^{25}$ ) Tofte skriver her fejlagtigt Carstens i Stedet for Karstens. Det var Hans Jørgen Carstens, som var Andenpræst ved Mariekirken og først i 1869 blev dansk Præst ved Helligaandskirken. Karstens= Klaus=Grumtoft her i Brevene. 
I Morges sendte jeg Jens [Sønnen] efter Salmenumrene. Jeg var i Perlehumør, havde slaaet op i Biblen paa Alteret Jeremias Begrædelses Bog, næsten tilfældigt. 2 Salmer synges. Præsten paa Stolen, en 60 Mennesker i Kirken, almindelig Opmarksomhed. Prædikenen begyndte med en temmelig heldig lille B $\phi \mathbf{n}$ om Herrens Velsignelse til Værket. Tekst: Vær ikke bekymrede for noget. Det er Høstpradiken. Uden videre Overgang fra Teksten, uden at man kunde se, hvordan han kom dertil, vilde han prædike om Guds Forsyn. - - - alt, hvad en Skoledreng ved at sige om disse Dele efter en Lærebog. En ren Kandidatsnak, tynd, men nogenledes godt holdt. - - - men saa kunde vi ikke Lektien, det gik rent i Stykker, et helt Stykke tabtes aabenbart, en Del meningsløse Sætninger kom frem, Slutningen kom dog uden Skandale. Han var aabenbart meget befangen, men jeg tror dog, naar Kandidatvandet er løbet bort, at han kan afgive en temmelig god Præst, synger smukt. Begyndelsen, ser De, var meget sørgeligº). Kiggede ikke saa sjalden i Papiret : næste S $\phi$ ndag faar vi kun faa Tilhørere! Lyses for et Par, den apostoliske Velsignelse. Med meget hurtige Trin ned i sit Lukaf. 2 Salmer. L $\emptyset$ b helt sur i Fadervor, vendte to Bønner om og glemte »Forlad os osv.* Efter Gudstjenesten Bryllup. »Skal De ogsaa være med derved? «Ja«, jeg skal«, sa' Degnen. »Skal der synges?«»Ja«, sa' Degnen. Vi sang som sædvanligt. Men saa, og det er det værste, saa læste, siger og skriver : læste han op for Brudgommen af Papiret en lang Tale om Kærlighed, Solens Aftenstraaler osv. Det saa jammerligt ud for Alteret at se Præsten læse en Brudetale; jeg vendte mig om. Han saa flov ud : min Nærværelse generede ham

26) Sammenlign et Brev fra Overlærer C. F. Monrad til Lærer Matz Matzen Fl. 2-10-64: , Vi har da i Dag for første Gang hørt vor nye Præst - Gud bedre det! Noget ynkeligere kan man ikke godt tænke sig: en (hakkende) ængstelig halv Oplæsen, halv Udenads-Fremtagen af noget Lirum-Larum, og saa til Slutning Venden op og ned paa enkelte Bønner i Fadervor og Udeladelse af en eller to af dem. Introduktion [Indførelse] af ham fandt aldeles ikke Sted. Uden al Indledning dukkede han op paa Prædikestolen og begyndte en Slags Høstprædiken, der hurtigt gik over til lidt Snakkeri om Guds Forsyn. Hver Dag bringer dog ny Forhaanelse af osle 
aabenbart. Han læser ganske godt. »Farvel, bor De i den gamle Præstebolig? «Ja«. »Farvel«.

»Nej, Pastor Holdt ${ }^{27}$ ) gjorde det dog meget ringere«, sagde Organisten. Tysk. Snit paa Præstekjolen samt Sladreflipper. Han \& $\phi \mathrm{r}$ vekselvis et St $\varnothing \mathrm{d}$ op, saa ned med den ene Skulder, saa med den anden. »Det er dog radsomt «, sagde Frøken Carstens bag Møllen. En anden mente: „Det kunde have varet varre«. Jeg mente: »Det bliver nok godt «. Politik maa man drive for Menighedens Skyld, men det hele var slet. 3 Steder Barnedaab i Dag, i Morgen et Lig.

Efter Middagsmaden gik jeg op i Skolen for at hilse paa Klaus. »Jeg tager mig den Frihed at hilse paa Deres Velærværdighed i Deres $\mathrm{Hjem}_{\mathrm{j}}$. »Ja, ja, ja! De maa virkelig undskylde, at jeg ikke har varet hos Dem; det er ikke af Ondskab eller slet Vilje, men rent tilfaldise Grunde, der har forhindret mig, og saa vidste jeg heller ikke, hvor De boede«. Jeg svarede intet.

Fik et Glas Portvin. Saa indsalvede jeg ham. Han var blæst fuld af alle mulige tyske Fordomme mod Skolen, fuld af de værste Løgne om os : „Vi var favoriserede, betaler ikke saa meget Skat som de tyske Menigheder, uddelte gratis Bøger til Børnene* og flere Ting, som Slagteren vist havde sjort i ham. Saa fik jeg Ordet, viste ham Løgnen Punkt for Punkt, saa grovt som muligt, fortalte ham, det var de samme Løgne, Slagteren troede, sagde ham, at Slagteren havde ytret: »saa skal de nok komme«, viste ham, med hvilket saligt Grin Slagteren ytrede dette : »det var som en Handelsmand, der glader sig over en god Handel« jeg slog paa Lommen og viste: »saaledes! * Fortalte, da han undskyldte Slagteren : »det var ham og ingen anden, der vilde gøre os Fortræd i Kirke og Skole«. I noget gav han mig Ret : »det var det ogsaa, men det havde sin berettigede Grund $\mathrm{i}$ det, som jeg kunde vise ham Punkt for Punkt, var Løgn«.

Han var aabenbart ked af min lange Nedriven paa Slagteren og de slesvig-holstenske L $\phi$ gnhalse, der bygger Skolen paa L $\phi g n$ og slaar Menigheden ihjel ved Hjalp af L $\phi g \mathrm{gn}$. Han lovede endelig: »han vilde se og prove og dømme» - den Dreng! Jeg sagde

27) Pastor Jacob Hansen Holdt, den tidligere danske Præst ved Kirken; under ham dalede Menighedslivet nærmest til Nulpunktet. 
ham: "han havde en let Post, han kunde slaa sig til Ridder ved at hjalpe at splitte Menigheden, men det kunde han ogsaa ved at hjælpe os med at holde den sammen; hvis han ikke vilde det sidste, saa hjalp han Slagteren med at gøre denne store »kirkehistoriske Skandale« at slaa en Menighed ihjel. Han kneb endelig ud med: »det var maske det heldigsie ikke at sige, hvad man var (han vilde dermed give mig til Kende, at han var dansk?), men hvad der var berettiget, vilde han holde paas.

Slagteren har haft ham godt under Behandling. Jeg er glad over, han fik sin Overhaling i al venskabelig Hoflighed, $f \phi r$ han skulde ud at dobe de tre B $\phi r n$ : $\gg$ Hos os kunde han faa de bedste Efterretninger om Kirke og Skole, og jeg var aldrig bange for at sige Sandheden; vi havde plejet Værket som et Kærlighedsvark, og Kærligheden døde ikke ud med én Dag, lige saa lidt som den kunde komme i én Dag«. Han fik saa Skoleregulativet, og jeg henviste ham til Arkivet, som han endnu ikke havde faaet. Man er forresten nok blevet bange for at opløse Menigheden endnu; det skal nok bie til Paaske. I denne Mellemtid skal Overtalelser og Tilbageholden af Skoleme splitte os ad; man venter ogsaa nok, vi i denne Tid omtrent $d \phi r$ af Mangel paa Penge. Noget af det fik jeg at vide hos ham, noget hos vor forrige Prast, men det stammer alt fra Slagteren, der synes at vare hleven lidt фmmere om Hjertet paa dette Punkt. Her har De nu lette Mфde. Han vilde bes $\phi$ ge mig, men kommer vist ikke saa snart; kommer han, faar han den samme Sang. Vil De ikke, naar De har last dette Brev, sende det til Munck; ellers skal jeg skrive det samme til ham.

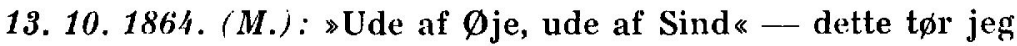
vel ikke anvende paa nogen af mine Præster, men De skulde prøve at sidde i babylonisk Landflygtighed, ene og forladt, uden at høre et Ord i lang Tid fra dem, man stadigt ellers omgikkes, og som man stod i niermere Forhold til, saa kan De nok forstaa, hvad Indledningen betyder : skriv snart!

Klaus prædikede i Søndags meget bedre. Hvad det angaar, saa kan det nok komme til at gaa nogenledes, maaske godt. Hans Forhold til dem af Menigheden, han kommer i Berøring med, 
er godt, tilbageholdent, men fornuftigt : de kalder ham en flink Mand. Overfor Menigheden roser jeg ham det bedste, jeg kan, dette er jo min Pligt. Han har endelig set ind til mig et $\emptyset$ jeblik. Forleden mødte jeg ham og Peters spadserende : to loyale Mænd, passer sammen, passer ikke sammen med mig. Skolen gaar sin vante Gang; vi opretter nu fem Privatpartier [Privathold] for at hjælpe noget paa den manglende Undervisning.

Jeg bliver $\mathrm{i}$ denne Tid ofte tung om Hjertet, naar jeg tænker paa den usle Fred, der jo forestaar os. Jeg ved ikke, hvad der er det værste: at frygte, men dog haabe, eller: at vide, man er solgt. Hjertet bløder ved Tanken om det sidste. I denne Stemning skriver jeg til Dem. Jeg vilde bede Dem om noget: Kan De sige mig, hvor længe jeg skal blive her, naar den usle Fred er der? Skal jeg saa straks rejse, eller skal jeg vente, til man fordrer noget af mig, eller hvorledes skal jeg? Jeg vil leve og dф som ret dansk Mand, vil ikke g $\phi$ re Ed til nogen anden end Danmarks Konge, vil ikke se min S $\varnothing$ n i tysk Uniform, vil hellere døje alt. Saa meget staar fast.

Nu havde jeg i Sinde at skrive til Indenrigsminister Heltzen for at faa en Slags Instruks, men ved nøjere Eftertanke lader dette sig ikke gøre : jeg kan naturligvis ikke vente noget skriftligt fra ham. Kunde De ikke hjælpe mig i min Vaande og skaffe mig en Regel og Rettesnor fra ham, gennem Regenburg ${ }^{28}$ ), Johansen $^{29}$ ) ? Jeg skal holde det hemmeligt, hvis det forlanges. Hvor læenge skal og kan jeg holde ud og dog blive ansat som ret Dansk og være pensionsberettiget i Kongeriget? Skaf mig Svar paa dette! De valter derved en Sten fra mit Hjerte og vil endnu gфre mig mere forbunden, wenn möglich [om muligt].

Gamle Jungquist har sagt til en af Menigheden: »Jeg ynker meget stakkels Tofte«, og i Grunden har han Ret deri : jeg er meget at beklage, hvis jeg ligesom De og Graae skal forlade et Værk, Skole og Menighed, som jeg elsker - men han mente: fordi jeg skal blive under en daarlig Præst. Dette vilde jeg dog nok holde ud, og jeg vilde med Guds Hjælp kunne bidrage

28) Regenburg havde 28. 1. 1864 svaret paa Provst Aleth Hansens Forespørgsler. Aftrykt i S $\varnothing$ nderj. Aarb. 1936, S. 38-39.

29) Rimeligvis Amtmand W. Johannsen. 
meget til at holde Menigheden sammen, hvis der var Haab om en nogenlunde god, endelig Fred.

Okt. 64 (M.): Klaus prædiker lidt bedre. Han har vist været dansk, for jeg synes, han har en slet Samvittighed : man kan se det paa $\emptyset$ jnene. I Bov er der en Præst, der hedder $\left.R \phi n n o v^{30}\right)$, tysk. I Bov Sogn er der ogsaa en ussel By med en gammel ussel Skolemestẹ, Hamann, har en meget lille Løn. Byen hedder Kragelund. Præsten var i Skolen. Efter endt Visitats Samtale mellem Rønnov og Hamann. Tilsidst sagde Skolemesteren: »Jamen, $\mathbf{H r}$. Pastor, hvor længe kan det vare endnu, f $ø \mathbf{r} æ$ Dansk kommer igen?« Præsten: „Hvad, hvad siger De?« (i højeste Dur) Skolemesteren: »Mon de Danske ikke snart skulde faa Hjælp? « Præsten: »Den Sag er jo allerede afgjort«. Skolemesteren: »Ja, de skal saamind nok komme igen; det har vel inne $\mathbf{N} \phi$ ' « Jeg fik Taarer i $\emptyset$ jnene over den gamle uskyldige Mand.

26. 10. $1864(M$.$) : Klaus prædikede godt i Søndags (30 i$ Kirke) og vil snart til at kaste Bladet. Brudevielse, god, frit holdt. I Dag har jeg været oppe at se, hvor smukt Børnene sad i Nissens Stue. De kan tro, baade Lærer og Børnene var glade over Forandringen. Den eneste, jeg fik Vrovl med, var Vognsen, hvem jeg maatte skalde Huden fuld. Jeg vilde haft Klaus op til Prins Carl for at faa Skolerne; det vilde han ikke. Forresten er han kommen til at tro paa, at Menigheden bestaar, ja, hvad mere er, det lod til, at han ved givet Tilfælde nok skulde vide at reklamere, hvis nogen vilde gøre Indgreb i hans Rettigheder som Menighedens Præst ved Barnedaab, Begravelser osv.

- - Det er i Grunden dumt at sørge for Fremtiden, den bliver nok lysere, end den ser ud, og kan der gøres noget for nogen, saa er jeg vis paa, det vil blive gjort for mig, saalænge Craae og Munck er derovre. Et bestemt L $\phi f t e$, Tilsagn, en Rettesnor at gaa efter, fra højere Steder, det var rart nok at have, da man saa i sin enlige Stilling (De maa huske, jeg har ingen

so) Pastor Rønnau var konstitueret i Bov, kom s. A. til Adsb $\emptyset$ lGraasten, 1865 til Ensted, 1867 til Emmerlev og endte 1875-1904 atter i Bov. 
at raadf $\phi r e$ mig med mere) lettere kunde holde ud for Sagen og derved give mine Medlærere godt Raad og godt Eksempel. - - Bed Graae skrive snart til en, snart til en anden af Menigheden; gør De det samme, det virker umaadelig meget godt.

27. 10. 1864 (G.): Skolelæreren fra Harreslev kommer vist Mandag 8 Dage til København; han medbringer vist, haaber jeg, J. Thaysen, D. M., afsat Regnskabsmand fra Harreslev, han er Hovedmanden i Hanved Sogn. Sørg for at gøre lidt Stads af han. Han er rig og af en Bonde at være en meget dannet Mand. Hilsen til lille Ingeborg fra Helga og Valborg ${ }^{31}$ ). $\gg$ Hvis Dansken kommer, skal jeg have min nye Kjole paa«, det er Helgas evige Sang. Hvis - naar. De beh $\emptyset$ ver ikke at være bange for, at jeg skal kyse klaus bort. Sommetider er jeg Sødheden selv. De ved jo übrigens nok, jeg har det Pund, at jeg kan sige til Folk, hvad jeg vil. Det er sommetider grovt nok, men af Tofte gaar det an.

30. 10. 1864 (M.): Medens De og Graae ligger i Hi, kunde De nok i det mindste hver Dag skrive et Brev til Flensborg, for at ikke de Kærlighedsbaand, der er knyttede, skal sønderrives. Kruse, Boi Jensen, Thomas Andresen, Zedeler osv. kunde have godt af et Brev med Formaning til at holde paa Menigheden ved at holde sig til Kirken. Jeg har tænkt paa, at hvis jeg skulde gaaet og dinglet i København, vilde jeg sammenkalde mine Kolleger til et M $\phi$ de og stifte en Forening, der skulde virke herovre ved at skrive Breve til Venner og Bekendte. Hvis der var saaledes flere Foreninger, kunde Lærerne tage sit Slags Folk, Præsterne sine, de høje verdslige Embedsmænd sine. Hver har dog nogle Y'enner. Naar saaledes hele Slesvig blev behandlet efter en vis Plan, kunde der komme noget ud deraf.

I Angel og de blandede Distrikter skulde de trofaste opfordres til at benytte det danske Sprog ved ministerielle Handlinger:

31) Toftes Døtre fik senere den Ere, at deres Fotografi i Nationaldragt udsendtes som Illustration til Holger Drachmanns „De sønderjyske Piger « (i „Derovre fra Grænsen«). Helga (død 1883) hviler sammen med Moderen (død 1877) paa Overs $\varnothing$ Kirkegaard. 


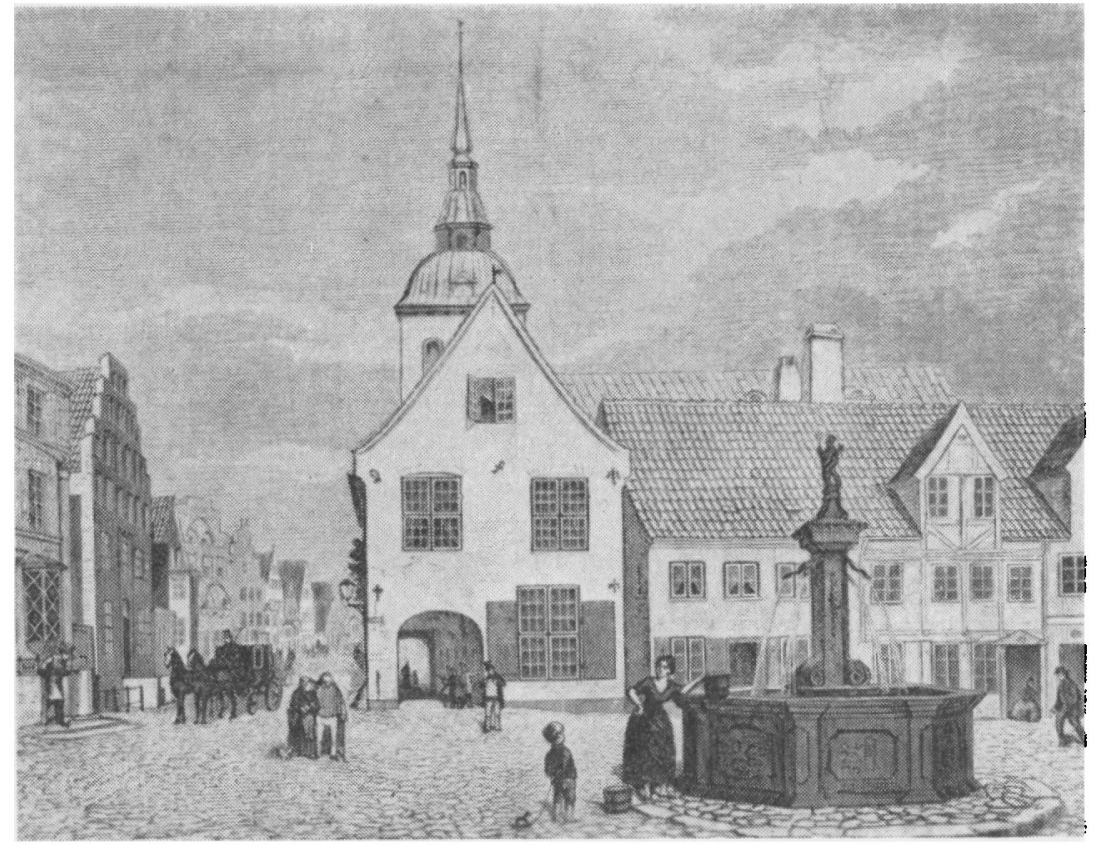

Norretorv med Neptunbronden on \$Schrangenष.

Litoglafi efter tegning af $H$. C. Ley omkr. 1860.

Daab, Altergang, Begravelse. Præsterne er n $\phi$ dt til at g $\phi r e$ det paa Dansk, om forlanges. Overhovedet komme frem med Ans $\emptyset$ gninger om Dansk osv. I Nordslesvig skulde der ansøges om de gamle Præster og den passive Modstand styrkes. Vor Menigheds Medlemmer skulde opfordres til at søge Kirken, flere, der ikke er i Menigheden, skulde opfordres til at træde ind deri osv.

Det er nu mine Tanker; det er et uskyldigt Middel, men De skulde vide, hvor højt simple Folk skatter et Brev fra en Ven, hvilken Ere det er at faa Breve fra en Overordnet. De kan tro, det vilde styrke, om man kunde se, at man ikke var helt forladt, at gamle Venner fra gode Dage mindedes dem $\mathrm{i}$ de onde, at de mærkede, at herovre bor Embedsmændenes Hjerte, deres Skat. Hvis det skulde give for mange Breve med ét Poststempel, saa sendes de andet Steds hen og stemples. Læg Dem bare iklke $i$ Vinters $\phi \mathbf{v n}$, men brug det eneste Middel herovre, der er tilbage 
for Dem at bruge: det skrewne (Ord. Kinder skriver til Kivinder, Børn til Børn osv.

I Dag skulde Freden komme. Jeg venter en god Fred i Form af en Helstat eller saadant. Dermed var jeg tilfreds. Den Frihed, som man har taget derovre forlods, maa gerne for mig gaa til en Tid, naar Staten kan holdes sammen.

1. 11. 186:4 (M.): Giv aldrig Hatabel op om Genforening med Danmark! I den sidste Tid er Haabet blevet starkere, hvorfor maa Gud vide; men det kommer, det føler jeg; gid det kom snart!

Freden er afsluttet. Efterretningen kom i Gaar, og i Morges dundrede Lappe ${ }^{3 \Sigma}$ ) los med Laarb $\not s s e r$ nede paa Broen, saa det var en Lyst. Stor Flagning fra Kirkerne (ikke fra vor), men der er noget mat over det hele : ingen Jubel eller Uro paa Gaden, ingen Illumination. Sig de angelske Folk derovre, at de trygt kan paaminde deres Venner om at benytle Dansk ved Altergang, Daab og Begravelse osv. Dette er nemlig et Paalazg, alle Praster i de blandede Distrikter har faaet, at de pai Forlangende skal benytte det danske ved slige Lejligheder. I Adelby har Pastor Hoeck endog forkyndt fra Pradikestolen, at det kunde ske. Det var en Skam, om det ikke ofte forlangtes. To Gange har det varet forlangt i Hulvejen [Lyksborggade], og Degnen maatte endog synge Dansk. Haardt nok for ham : i Pastor Lassens Tid blev Sangen nok altid givet germanisk [tysk].

Jeg har været omkring for at purre ved Menighedsmedlemmerne med Hensyn til Kirkegang. Nogle Penge maa jeg have i Stedet for den aarlige Indsamling; Underst $\phi$ ttelsesforeningens, hvordan skal jeg faa fat paa dem? Kan De skaffe Raad, ellers skriver jeg til Grevinde Danner om et Par Hundrede Daler eller saadan noget til Uddeling blandt træengende $i$ den danske Menighed. Sig mig hendes Adresse! Skriv straks om den Ting! Faa nu en ordentlig Skriverstue i Stand! Den vil udrette meget godt! Kan Hjerterne bindes til Dammark, saa maa Kroppen følge.

:2) Iflg. Gustav Johannsens Brev til Regenburg 5. 11. 64 var Lappe

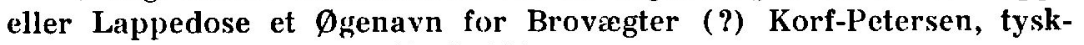
sindet. Sønderj. Aarb. 1940, S. 203. 
7. 11. 1869 ( G.): Nu maa Regenburg da vist kende Fredsbetingelserne, og De vil tjene mig og mine Medlarere sardeles meget, lıis De pata en eller anden Maade kunde skaffe os at vide, hvad Regeringen vil have, at vi som gode Danske skal gøre nu, naar der efter Fredsbetingelserne stilles denne eller hin Fordrings til os. Vil den have, vi skal blive, eller skal vi traede af, naar Kongen lyser os fra Eden, eller hvad vil den, vi skal gore? Disse Sporgismaal beskaftiger os meget : fra Eden vil nok kun Werner lade sig lose; han vil ligesom Micholsen gata gennem tykt og tyndt med Slesvig. Bliver der Personalumion, saa vil vi andre ogsaa hlive; i modsat Fald er det mign en Umulighed, naar jeg ikke ligefrem vil begaa Selvmord : mange Aar kunde jeg nemlig ikke holde det ud som aftraadt til Tyskland. Menigheden og Skolen vil jeg imidlertid ofre mig for, og det vil Laxerne ogsaa, hvis det paa nogen Maade kan gavne Sagen, saa lange som muligt. Kare Pastor Graae, De ved nok, hvad der rorer sig i mit Sind i den Retning, og De ved ogsaa nok, hvor vidt jeg vil gaa, skaf migs og os en Regel og Rettesnor, eller et godt Ratad fra den trofasteste Slesviger, fra Regenburg, og De vælter en Sten af vort Sind!

Deres Brev til Fru Clausen gijorde gorlt, hror det kom. Der (r mange, der langes efter Brev fra Dem i Byen. I Anģel har jeg talt med flere, der venter Brev derovefra, fra Provst Hansen, fra Pastor Lassen, Krog, fra Vissen osv. Man klager almindeligs wer, at de tro her nu er rent glemte. Kan et Brev hjælpe, saa er det ligefrem Synd, om de afsatte Embedsmand ikke stadigen skriver. Yi har flere Børn, and da Munck rejste. Dansken er scjor. Hvilken Sejr, hvis De og Munck en skønne Das kunde drage ind her igen! Deres Gavess) bliver smuk; jeg ser den engang imellem. Der arbejder daglig 3 Guldsmede derpaa.

11. 11. 186/ (M.): 'Tyskerne er lutter Liv og Virksomhed : de sidder paa Knejper og $\emptyset$ lstuer til den lyse Morgen. Danskerne ser derpaa, lader det ske, hrorfor? lin Grund er: de sover den lelejlige Tid bort.

33) Den danske Menighed forerede Pastor Graae en Solvopsats til Jul 1864, se G. F. A. Graae: $* 48$ og 64« (1886), S. 182 f. 
I Gaar blev ombragt til ethvert Hus i Flensborg 》Spфrgsmaal og Svar for Beboerne i Slesvig-Holsten«. Skriftet er 2 Kvartblade ug indeholder: Hvad har Hertug Peter af Oldenborg gjort for Slesvig-Holsten? Gennem mange Sp $\varnothing$ rgsmaal og Svar kommer man til det Resultat: Hertug Peter har ikke villet have den danske Krone, fordi han ikke tillige kunde skabe et frit ogs selvstændigt Slesvig-Holsten. Han har foranlediget Rusland til at fratræde London-Protokollen og derved hindret England $i$ at yde Danmark Hjælp; han har formanet Frederik VII; han har solgt Preussen Jahdebugten, for at Tyskland kunde faa en Flaade; han vil ogsaa aabne Slesvig-Holstens Havne for Preussen. Hertug Peters Land har den frieste Forfatning $i$ hele Tyskland. Han er altsaa den mest passende Hertug for Slesvig-Holsten. Videre indeholder Skriftet: Hvad har Hertug Frederik af Augustenborg gjort. Han har besvoret Grundloven; saa følger alle hans Udyder; ham skal I ikke tage til Hertug. Det var nu det.

I Aftes var der Stiftelsesfest i Harmonien. Man spiste godt og drak tat. Ved 4 Skaaler rejste Danskerne sig ikke. Fjenden blev sprøjtefuld, kravlede omkring, kyssede og kærtegnede osv. Vi er rigtig muntre over Skandalen. Direktionen har været kaldt op til Zedlitz i Forh $\varnothing$; man taler om, at Selskabet skal opløses og Bulen lukkes. For os gerne. Forresten vil jeg gøre opmærksom paa, at nu begynder Satans Rige at blive uens med sig selv; gid det ogsaa kunde blive $\varnothing d e ! ~ N u$ er det ikke ret langt fra, at Danskere og Slesvig-Holstenere kan blive enige om at valge Danmark til Fædreland. Jeg talte med Klaus derom; han mente, om ikke lang Tid var det muligt. Paa den ene Side stod Frihed og mildt Regimente, paa den anden Side Preussen mere beh $\emptyset$ ver man ikke at sige. Gid nu bare de dovne Slesvigere i Kóbenhavn vil udnytte det gunstige $\emptyset$ jeblik og hver $i$ sin tidligere líreds trøste, opmuntre, styrke, kort sagt skrive og holde Danske i Aande. Det skadede heller ikke, om man skrev til en halvblods om et og andet. Gid man bare vilde udnytte den kostbare Tid! $\mathrm{Nu}$ er det Tid, nu er Slesvig tabt; det kunde dog være, vi kunde komme til at sige, sige snart: den Dag Slesvig tabtes, den Dag vandt vi Slesvig $\mathrm{J}$ : hele Befolkningen. 
18. 11. 1864 (G.): Regel og Rettesnor for mit Forhold her nu, kan jeg jo se, man ikke kan eller vil give os, hvorfor vi jo hliver nфdte til at gaa efter vort eget skave Hoved. Er det Søvnighed, (ler forvolder det i København, saa kan det sandelig ikke undskyldes; men der kan vel tænkes andre Grunde. Proklamationen er da heller ikke kommen endnu, og saa længe er der Tid. Michaclsen har allerede kysset Riset : han ordineres idag og skal være konstitueret Præst i Uge. Hvad skal vi andre gøre? Ligesaa? Jeg kan ikke : Freden har jeg ikke sluttet endnu; wühle [agitere], det er min Bestilling for Fremtiden, naar jeg er færdig her. Hvor faar jeg noget at leve af, naar jeg bliver afsat? Derover bekymrer jeg mig endnu ikke; men det var dog værd at vide det.

Skolerne har vi ikke faaet endnu. I Gaar var Berider Hansens Kone oppe hos Zedlitz og spurgte, hvorfor han endnu ikke havde holdt det Løfte, han for 14 Dage siden gav, og sørgede for, at vore Skoler blev tomme. Han: »Min gode Kone, det kan jeg ikke ene gøre; henvend Dem til Magistraten, den er nu lige forsamlet . Hun gør det straks: »Jeg kommer fra Zedlitz og vilde gerne spørge, om De ikke snart kan rømme os vore danske Borgerskoler. Callesen: „Hvilken Interesse har De deraf? « Svar: 》Det skulde jeg mene, jeg har Interesse deraf : 2 Børn har jeg i Skolen os det tredje skal snart derhen«. Henningsen fra Broen (halv tosset af Tyskhed, Lærer Schumanns gode Ven) siger: \Jeg kender Deres sma nydelige Børn. De taler lige saa godt $\mathbf{H} \phi \mathbf{j}-$ tysk som jeg; send dem over til Schumann! "Svar: »Nej, jeg er i den danske Menighed; jeg er lart paa Dansk, min Mand taler bedre Dansk end Tysk; saa længe den danske Menighed bestaar, skal mine Børn gaa i Skole der «. Callesen igen: „Den danske Menighed bestaar ikke længere«. Svar: „Det skulde jeg dog mene; hvorfor har De ellers sendt os en Præst? Var der ingen Menighed, behøvedes der heller ingen Prast «. En gammel Mand for Bordenden - det var naturligvis Bremer, med flere Protokoller foran sig - siger vredt til Talerne: »Den danske Menighed bestaar $\mathrm{i}$ det mindste indtil Paaske, foreløbig «. Andreas Jensen: »Madam Hansen, de har allerede begyndt at tømme Skolerne i Dag; jeg tænker, de bliver snart fardige; saa kan de jo straks 
tages i Brug«. Saadan l $\phi b$ det af : man fik dog noget at vide derved. Skolerne bliver imidlertid ikke t $\phi m$ te endnu : Byen $g \phi r$ gode Forretninger med vore Skoler! De er formentlig udlejet til Preusserne! For den i Norden [Nystaden] er der fordret i Leje 800 Mark Courant.

20. 11. 186 (G.): Kirkeaaret sluttet med over 100 Tilh $\phi$ rere. "Saa siger vi hverandre Farvel var Slutningssalmen. Pastor Carstens fra Marie prxdikede, da Claus havde en daarlig Mave. De 100 var komne for at hore Claus. Endnu, og det er meget glædeligt, kan vi i kirken maale os med de tyske Kirker, hvad Tallet angaar.

- - - Det er ellers det svareste, jeg har oplevet, at se Kongens I'roklamation, hvorved man løses fra det sidste Baand til Konge og Fædreland. Jeg har haft mange, mange Skrupler i de sidste Dage om, hvad jeg skulde gore : nedlagge mit Embede eller blive, blive altid eller til man fordrer nogen ny Ed eller deslige af mig. Har raadf $\phi$ rt mig med Fanilie og Venner, med Evaldsen"s), der vil nedlagge Embedet, med Biskoppen [Boesen], den elskvardige samle, der mener, begge Dele er lovlige, med Michaelsen, der siger absolut: hliv! Naar jeg tanker paa Menigheden, saa maa jeg blive, i det mindste indtil den er oplost eller har faaet en fast Skikkelse. Naar jeg tanker paa det faste Haab om Genforeningen med Danmark, hvilket enhver Dansker herovre har, jeg med, saa maa jeg blive; men sporger jeg Sindet, det siger: af Sted til Danmark, for din Søns, din Families Skyld! Det er en sver Kamp : lige saa mange Gange, som jeg beslutter: gaa! lige saa ofte beslutter jeg: bliv!

Af en gammel Ven og Medarbejder [som Dem] havde jeg ventet et Raad, $i$ det mindste fra Ministeriet det Svar, underhaanden gennem Dem, at jes, enten jeg kom nu eller senere, vilde blive modtaget som en god Dansk og faa Pension; jeg har jo Familie, det trykker ogsaa. Kongen har lost den ene Ende af Eden : jeg holder den anden fast; ingen kan lose mig far Eden

34) Pastor Chr. Ewaldsen ved St. Nikolaj Kirke i Flensborg. Breve fra ham er aftrykte $i$ min Bog „Fra sydslesvigske Prastegaarde * (1938), S. 65-70. 
uden jeg selv. Egentlig, kan jegs nok marke, er jeg skabt til al wühle [agitere], faa Pension og arbejde under Haanden [Jorden | her, dertil staar egentlig min Hu, naar jeg ikke med Ere kan hlive ved Menigheden her.

Fra Borgmester Funke, den rare Mand har jeg hørt (det er talt hos den brave Frederiksen i Nystaden, Funkes Svoger, og bragt mig af en dansk Spion, min Ven), at Menigheden endnu $i$ inderarende Uge skal forandres, men om Oplosning var der ikke Tale. - Endnu Kors paa Brystet og 6 Dannebrogsflag i Kirken.

29. 11. 1864 (G.): Klaus betroede mig lige, at Menigheden kun havde nogle faa Dage at bestaa $i$. Menigheden ril $i$ denne eller næeste Uge blive oplost, og Klaus formodentlig til sanme Tid blive udnavnt til Prast ved Helliggejstkirke. Skolerne skal da lægges under forskellige Praster : den i Norden under Mariekirken, den i Syden under Nikolaj K.; Plankemai-Skolen skal ophaves. Skolerne skal forøvrigt hestaa til Paaske. Der har De det lige saa varmt, som jeg har faaet det. Slagteren sejrer altsaa; ul burde han have det. Forleden var jeg ved at tænke over Sagen og skrev nogle Tanker op, der paa en endnu krassere Maade burde sattes i Avisen. Her kan De se mine Tanker; lad Slagteren faa det! Hvilke Demonstrationer skal Menighedsmedlemmerne nu gøre osv? Skriv mig Deres Tanker derom! Børnetallet er vokset til ca. 490 .

30. 11. 1864 (G.): Klaus vedgik i Dag, at Slagteren ikke havde sjort Modstand nok, og derfor blev Menigheden opløst. Jeg: ¿En Vinterindslagtning! K Klaus vedgik, at det gode ved Sagen kun kom fra Zedlitz; dette er troligt nok : Magistraten fordrer Opløssningen efter Provst Peters Raad, Zedlitz giver efter for det almindelige Storml $\phi b$. Dette er min Mening om den Ting. Klaus plumpede ud med, at han havde talt med [Biskop] Godt (Præsterakkeren ), om det gik an, at Menigheden betalte to Steder ved ministerielle Handlinger. Det syntes Klaus naturligvis ikke; derfor skal der kun betales til den danske Præst, men de skal indf $\phi$ res $i$ de paagaldende tyske Ministerialb $\phi g e r$ maanedsvis. 
Præstepengene faar de Kæltringe altsaa. Naar Skolerne saa kommer under tysk Inspektion, saa er Sagen klar : jeg venter, at de skal indrettes efter tysk Mфnster og saa efterhaanden fortyskes; det er Udsigterne. Jeg vil holde ud til det yderste og se Spillet an : det vil blive interessant, skønt sørgeligt. Endnu er Opløsningen ikke sket; maaske (jeg haaber det nappe) kan det reddes endnu, naar der kommer en Salve i de danske Blade.

I Eftermiddags har jeg varet ude og faaet 4 Deputationer sat sammen : de skal op til Zedlitz om en og samme Ting, Menighed og Skole. De skal komme som tilfaldigt paa 3 forskellige Dage : i Morgen Feddersen med sin, i Overmorgen Freudenreich med én samt Theilgaard med sin, følgende Dag Fskildsen. I Norden virkes der for, at der melder sig nogle ind i Menigheden : dette er for Klaus' Skyld. Paa Søndag Fredsprædiken i den danske Kirke. Jeg gør alt, for at den ikke skal hlive holdt; det er en farlig Bestilling, men jeg maa se at drive dem bort, der kommer - med Lempe kan man faa et $\mathrm{Eg}$ i en Humlesæk; det bliver vel ikke saa svart endda. Der er $38 \mathrm{Kon}-$ firmander i Aar, 2 kommer til endnu, altsaa 40. „Det vil forbavse Verden at hфre dette $\ll$, sagde Klaus, »at der er saa mange Konfirmander i dansk Kirke«. Jeg mente, det var meget naturligt, forstod iøvrigt ikke Klaus' Mening.

3. 12. 1864. (Telegram til Graae): Den danske Menighed er opløst 30 (23) November.

3. 12. $1864(G$.$) : Det gik ikke saa lige med Deputationerne,$ som jeg havde ventet : i Dag har der først været én: Duseberg og Theilgaard. Den katolske Præst og jeg er endnu meget gode Venner. Vi var enige om, at det var rigtigst, at vi overlod Katolikkerne Kirken i Morgen fuldstændigt til deres Gudstjeneste ${ }^{35}$ ). Lederer [den $\emptyset$ strigske Civilkommissær] var enig med Præsten derom, men Visitatoriet afviste det, Peters nemlig. Lederer

33) Efter at Katolikkerne havde faaet deres egen Kirke bygget, sendte Pastor Rave den danske Prast en Tak for at have maattet medbenytte den danske Kirke gennem ca. 11/2 Aar. 1. 4. 1866 (Mariekirkens Arkiv). 
ytrede, det var ubehageligt for hver Dansk at holde Takkefest, derfor var det en nem Maade at fritage os derfor; men Slagteren ytrede: »Der kunde jo gaa i Kirke, hvem der vilde«. Planen, som jeg glædede mig meget over, gik saaledes i Stykker ved Peters', Magistratens og, hvad der er betegnende nok, ved Zedlitz' Hjælp. Den katolske Præst sagde jeg i Dag, han kunde af denne Historic sc, at Katolikkerne var her hadede lige saa meget af Tyskerne som vi Danske. »Ja«, sagde han »det ser jeg; men der har ogsaa været en Scene mellem $v$. Lederer og $v$. Zedlitz ved denne Lejliglighed. Ja, ja, nu staar jeg med Danskerne«. Jeg: »Vil De skaffe os vore Skoler, saa skal jeg overlade Dem en Skolestue« (de vil gerne have en Skole - der er 10 katolske B $\phi$ rn - de kan saa faa Tanks). Snart ved Lejlighed vilde han fors $\phi$ ge det hos Lederer, som jo er hans intime Ven,

Vi kommer nok til Danmark igen, derom nærer jeg ikke den mindste Trivl. Skulde jeg blive afsat, vil jeg sфge Pension her, siden leve deraf, saa søge Koncession som Kniplingskræmmer og saa handle i hele Slesvig og uden Forlov wïhle [agitere]. Min Kone skal, om Gud vil, i varste Tilfælde tjene Brødet til sig og Ungerne. »Det skal nok gaa«, siger hun. Tak skal De ellers have for Deres Brev og den Tjeneste, De tilhød mig ved Biskop Martensen! Jeg venter, jeg paa denne Maade let fik et Embede, men saa var jeg ikke her, og her er da ret egentlig min Vej til Ros og Magt. Jeg har virkelig det Haab, at denne Tid vil føre til Danmarks og min Lykke.

4. 12. 186 4 (M. og (G.): Klaus bad mig komme op. Jeg kom og fik se 3 Dokumenter: 1. Klaus' Udnævnelse til Præst ved Helligaandskirken med Bolig indtil videre $\mathrm{i}$ den forrige Kateketbolig og 840 Mark Courant. 2. Den frie danske Menigheds s Sognebaand (das Gemeindeverband) er ophævet, dog skal den danske Præst være berettiget til at udf $\varnothing$ re alle Ministerialia og modtage Petaling herfor; der skal ikke betales 2 Steder, men han er ikke berettiget til at fore Kirkeb $\phi$ ger; de skal indf $\varnothing$ res i de respektive Protokoller uden Godtg $\oint$ relse. 3. Skolen paa Plankemai skal snarest muligt nedlagges. Skolen i Graven skal staa under Nikolaj, 
og der skal Bornene fra Nik Sogn gaa; den i Norden lagges under Marie, og der skal Byrnene fra Marie Sogn gaa. Skolerne kaldes »Borgerskoler med dansk Sprosis; de bliver bestatende som hidtil, tror jeg til Paaske. Den hidtilvarende danske Degn faar sin I $\not$ in af Statskassen indtil Paaske. Min Tid er altsaa ikke lang, hvis Tyskerne maa raade. Nu er jeg opsat paa at drille dem, saa laxnge jeg kan. Nu vil jeg med Guds Hjalp vise de tyske Slyngler, at der or aseste jysk Sejghed. Sagen giver jeg aldrig (p. Gud styrke migs og os alle! derom beder jes tit af ganske Hjerte. Kirken var bes $\phi$ gst $i$ Dags af 50 Folk, saadanne, som ellers ikke kommer i Kirke. Se at faa den tyske Menighed i Kobenhavn til at hyle over Voldsgerningen her! Hyles og demonstreres skal der!

11.12. 1864. (G.): Tak for det tilsendte $\left.{ }^{36}\right)$ ! Skarp Lud! Klaus, som jeg fortalte om det, spurgte hurtigt: »Er jeg med? « Mange har last det med Fornøjelse. Klaus besøgte jeg forleden Aften. Han var meget fidé]; jeg matte ncidvendigt sidde ned og ryge en Cigar. Rieven vilde vide, om Menigheden nu vilde ghre noget. Vidste det ikke. Samtalen blev laengere og varmere, end han og jeg havde troet. Peters fik Smor af mig for Menighedens Skyld. Klaus forswarede Sagen : det var ikke berettiget, at mange var i Menigheden; de hørte hjemme i andre Menigheder ifølge deres plattyske Sprog osv. Jeg: De maa vide, at den danske Menigheds Medlemmerne ikke er en Flok Faar, der er drevne sammen, men fornuftige Mennesker, der frivilligt er traadte sammen. Han blev ved med sit »uberettiget«. Jeg tog da Anledning til at sige ham, at »det var Synd«, han var bleven Prast red en Menighed, som han fra forst af havde Fordomme imod. Det bed, og han blev rød. Siden fik han det endnu engangs, og til Slutning: det er baade Synd og Skam, De er bleven Præst ved vor Menighed. Han rystede, men jeg holdt mig. Han svarede: »De skulde se, hvilken Prast De vilde faa, hvis jeg kom bort«. »Det red jeg nok : en

36) Graaes hvasse Artikel „Ødelaggelsens Vederstyggelighed om den danske Menigheds Ophævelse i "Fadrelandet" for 18. 12. paa Forsiden er aftrykt i Graae $* 48$ og 64 . S. 175 ff. 
ren Slesvig-Holstener, Valentiner $r^{35}$, i egen Person, hvis Embedet var stort nok«. Arrigere blev Staklen, og dog endte vi som Venner. Han kalder altid Menigheden »Deres - Toftes Menighed «. Han har ingen Lod og Del deri. Fra Werner. den magelys brave Sjal, skal jeg hilse begge mange Gange. Er glad over Kongens Rejse og Slesvigernes Modtagelse $\left.{ }^{3 \star}\right)$, Ruslands Depesche det er Grund nok til Glaede.

18. 12. 1864 ( G. og $M.):$ Munck forer en meget blødere $\operatorname{Pen}^{39}$ ), har for blodt et Hjerte til at vare Stridsmand. Klaus lirkede ellers for mig om, at Menigheden burde demonstrere nu : De vandt vist noget derved, f. Eks. fik Skolerne i Foraring. Jeg er vis paa, det er Peters' Ord. Dette hanger efter min Mening sammen med Spqrgsmanlet om 》berettiget eller uberettiget». Efter min Mening skal Menigheden nu holde sig rolig og ikke arbejde Peters og Klaus i Handerne. Dette lyder vel underligit nok, men er dog sikkert Sandhed : man vil paa cengang mildne »den ugudelige Gerning\& ved at give Lov til en Slags Menighed under Klaus og saa, da man maa vere vis paa, at der ikke vil melde sig mange ind igen i den saaledes nydannede Menighed, saa vil man bevise Verden, at det mesie af det, der var $i$ Menigheden, var uberettigel. Pastor Friis var her i Das; han blev udmarket modtaget i Harreslev, i Morgen vil man derfra give stort M $\phi d e$ ved Dampskibsbroen til Afsked med ham. De skulde se en hjemvendende Prasts Modtagelse, den er rorende! De og Munck maa ikke søge! Gladeligg Jul! Godt Nytaar! Vi synger Juledag vore sadvanlige Julesalmer dette er dog én Trosst.

29. 12. $186.4(M . \circ g(x):$. Godt fuldt Hus Juledag, ganske godt 2. Juledag. Klaus viste sig efter de 2 Gudstjenester meget fidél;

37) Den meget tysksindede Pastor Chr. Aug. Valentiner, Prast ved Mariekirken 1837-50, afskediget af Danskerne.

${ }^{38}$ ) Den 7. 12. 1864 modtog Chr. IX $\mathrm{i}$ Kolding en Deputation af lienved 5000 Slesvigere fra Haderslev, Aabenraa og Flensborg Amter (Franz v. Jessen: Haandbog i def nordslesvigske Sporgsmaals Historie, (1901), S. 622).

sa) i Artiklen Den frie danske Menighed og den danske Borgerskole i Flensborg (*Fædrelandet « 12. 12. 1864 Forsiden). 
han er dog vist et godt sølle Skrog. Jeg roste ham og han mig ganske voldsomt. Vi enedes kønt on Gudstjenesten Nytaarsaften : Kl. 5 med straalende Belysning : 90 Lys. Meget stor Julegavefordeling 7. Januar, om Gud vil. Frk. Carstens, Mqiler og Klyver foranlediger det og har meget Held. Om Gud vil, synger vi dog for 14. Gang »Nu titte til hinanden «, dette er mig et godt Omen [Varsel]. Kunde man bare se et og andet Lysglimt! Jeg trænger saaledes dertil. Mismod melder sig undertiden, men saa skal jeg trøste andre, og saa faar jeg selv Mod.

Skolen i Norden tages til Lazareth eller som man ogsaa siger, til Skomager - og Skræddervarksted. Skolen i Graven rømmes, og vi drager ind der, om Gud vil, den 9. Werner skal bo i Sommers Lejlighed hos Klewing; der faar vi 2 Skolestuer. Vi begynder altsaa den 9. med fuld Kraft. Det bliver Lykke; gid det maa vare ved!

1. 1.1865 (G.): 64 sluttede med, at vor Kirke var saa fuld i Aftes, saa at Folk stod langt ud paa Gaden; i Dag var den ogsaa fuld. »Bliver det saaledes ved «, sagde Klaus, "saa faar Menigheden sine Rettigheder igen. Han er besejret. Jeg har flere Gange lyttet til Suk fra Klaus som disse: »Sikken Menighed, sikken Gudstjeneste; det var dog rigtig slemt, det gik i Styk ker for mig osv.* Det var Begyndelsen. I Dag er han overvunden. Han har begyndt at hilse paa Cancelliraad Carstens; Monrad ${ }^{40}$ ) hilste han paa i Kirken, og jeg haaber, han fortsætter. Onsdag eller Fredag holder vi Gudstjeneste i Lazarettet. Den katolske Præst fortalte jeg, at vor Kirke var propfuld i Aftes. $\gg$ Ja, det ved jeg nok «, svarede han, »jeg var ogsaa nysgerrig for en Gangs Skyld, men jeg kunde ikke komme indenfor*. »Det vil vist ikke smage Byen «, sagde Klaus; men det faar være. Mig smager det godt. Enden god, alting godt.

Tak for alt! Gid Aaret maa føre mine Præstefamilier herover! Viljen har jeg nok til at kæmpe, men Underst $\varnothing t$ telse fra sine Foresatte var en herlig Ting; den kommer ikke, f $\phi \mathbf{r}$ de gamle kommer igen.

40) Kollaborator C. F. Monrad se Kirk. Samfunds Julebog 19:33, S. 71-89 og S $\varnothing$ nderj. Aarb. 1952. 
17. 1. 1865 (M.): Min Kone har i de sidste 14 Dage varet saa betænkelig syg, at jeg har frygtet for hendes Liv. For Resten skal man kende sine Venner i Nøden, og jeg maa tilstaa, at det langt har overgaaet min Forventning at se al den Venlighed og Deltagelse, der er vist mig og min Kone i hendes svare Sygdom fra saa mange her.

18. 1. 1865 (G.): I Morgen, om Gud vil, begynder vi vor Skole helt med 6 Klasser, hvori saa alle Bornene indpakkes. Jordemoderen i Hanved fik nyligen et kgl. Bager til sit Barn, deraf gaar der voldsomt Ry. Det var forevist flere Steder her i Byen, det skal være meget smukt.

2. 2. 1865 (G.): Forleden havde Værtshusholder Thomas Andresens Datter Bryllup med en Skibskaptajn. Langt over 106 nysgerrige Damer i Kirken; Klaus helt forbavset derover. Almindelig Flagning med Dannebrog fra Skibene. Jeg første Gang med til Bryllup i Flensborg. Musikken begyndte med sVift stolt paa Kodans Bølge«. 50 Flensborgere til Stede; der taltes Dansk hele Tiden. Tofte matte danse til $2 \frac{1}{2}$ om Natten, gamle Stymper, Mor sad hjemme i god Bedring. Nok et Bryllup i Vente. Peters fik for Tillysning 8 Mark, 4 Sk., Klaus kun 4 Mark.

6. 2. 1865 (M.): Idag for et Aar siden. Idag stor preussisk Parade ved Overs $\phi$, Stor Flagning. Frederiksen (Oliem $\phi$ llen); men unter uns, lod imorges sin Skonnert ved Broen heise Dannebrog paa halv Stang : alle Skibe Dannebrog paa halv Stang . . .

De trækker for $\emptyset$ jeblikket et stort Læs [i Understøttelseskomiteen]. Jeg vil gjerne kigge Vorherre i Kortene : Det var altsaa derfor, De skulde vare det Par Aar ved Menigheden i Flensborg, hvorfor jeg skal blive, og hvad Herren har tiltænkt, grubler jeg undertiden paa, men da jeg har en god Herre, saa frygter jeg ikke; godt Hum $\varnothing \mathrm{r}$ har jeg, godt Haab tillige.

27. 2. 1865 (G.): Klaus er valgt til Præst i Kliplev. Provst Peters ytrede forleden til én, der bler gift i vor Kirke: »Her kommer de løbende og vil vies i den danske Kirke, én og hver- 
anden; disse Íunster skal vi snart vanne dem af med.« 'Til én, der vilde have sit Barn ud af Schumanns Skole og ind $\mathrm{i}$ vor Skole, brugte han en frygtelig Kaft: $\gg$ Hvorfor hun dog vilde det, hvad Nytte det kunde være til? til Paaske hgrte Skolen rent op osv.«

Nu kommer det, hvorfor jeg skriver. Skulde nu til Foraar, til Paaske, som alle Spaadomme lyde, vor Skole hlive opløst, kunde der saa derovrefra ventes Underst $\phi t l e l s e$ til en Skole, oprettet af os afsatte Laerere, og hvor stor kunde Underst $\phi t t e l s e n$ blive? Endnu har jeg kun talt med Werner om den Ting; men vi er cnige om at g $\phi$ re, hvad vi kan, for om muligt dog at frelse noget $o g$ nogle. Med Guds Hjæelp beholder vi vel Livet, da er Penge ogsaa gode, men hvis vi bliver afsatte, da vil Trangen vel sagtens blive stor nok, og det var godt nok omtrent at vide, hror stor en Hjelp der kan ventes, hris Ulykken skulde ske.

6. 3. 1865 ( $H . \circ g$ G.): Tak for 362 Rd.! Idag er Kóbmand Schroder her sat i Hullet, fordi en vis Mand fra Bov havde bekendt, at han havde befordret Adresser sendt til Napoleon. Iaften kommer han nok lọs igen, om paa Caution, ved jeg ikke. Gendarmerne hentede i Søndags 3 forskellige Mrend fra Bov; de var angivne, formodentlig af Præst eller Degn. Je bekendte straks, at de havde underskrevet, havde varet forsamlet hos en Nielsen $i$ Vejbiek $\left.k^{41}\right)$.

I Kollund var for en Tid siden Gilde med Bal, Prasten var tilstede, udbragte en Skaal for Deutschland. Den blev besvaret meget djærvt af en Mand, der havde varet dansk Husar, med et saadant Nakkedrag (bogstaveligt sandt), saa han dejsede om paa Gulvet. Han sagde intet, men vil ikke mere til Bal. (Husarens Navn er Petersen, og han vil blive Ejer af Wassersleben). I Mein var der Ringridning; alle Heste og Kongen rosde og hvide. I Tastrup Bal, hor 'Tyskerne blev udjagede.

I denne Maaned reiser der herfra til Fredericia 16 Familier, Cigarmagere. Gud velsigne Kobenhavn for de mange Lnderstgt-

41) Tidligere Iaxerer, nu Landmand Christian Nielsen flyttede senere til Flensborg og blev 1891 Direkt $\phi r$ for Flensborg Volksbank«. (Om ham se Haandbog, $S$. $600 \mathrm{f}$. 
telser, der flyder hertil. Deraf kan vi tydeligt se, siger vedkommende, at de har Haab derove endnu. Vi har Haab nok, Varsler nok. Gud styrke vort Haab, og gid Sagen snart maa vinde

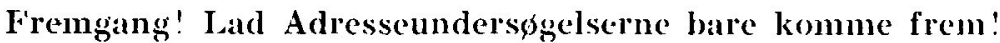

Nu er Volquarts bleven Provst til 1. Marts. Han holdt Iaxermode i Sct. Johannes Menighed. Der var tale om at oprette en ny Klasse, hvilket Laererne bl. a. motiverede med, al til Foraar kunde der ventes 'Tilgang fra den danske Skole paa Plankemai. »Hvad, er her en dansk Skole, her i St. Johannes? Hvor stor er den?« Skoler her endnu?" 》Den tieller nasten 500 Born.« „Det kan slet ikke tillades i en By som Flensborg! " Der kan De laese Dommen. Det skulde more mig at modlage Hr. Volquarts til Visitats; maaske faar vi den Ere. Han skal forresten vare den skinbarlige Satan, skønt 75 Aar.

9. 1. 1865 ( $M$. og (r.): Udsendinge fra Harreslev og Froslev var igaar hos Zedlitz og forlangte Indlorelse af Dansk igen i disse 2 Iiyer og noget i Kirken osv. De fik talt med Z. temmelig lange, og, som jeg tror, godt. Det var den lille Moller og Rossen. Ft Mylder iaftes paa Gaden uden Lige. Kongens [Christian IX] Skaal blev drukket i hvert dansk Hus og i hver Knejpe; jeg endte Dagen med at drikke 2 Kaffepunse. Jeg havde 5 Harreslevere tilbords iaftes.

16. 1. 1865 ( $M . \operatorname{og}(\dot{0})$ : Glaedelig Fest! Kirken luld, propfuld Fredag og idag. Klaus tager Afsked imorgen. Carstens er constitueret i Mellemtiden. Godt og vel. Intet Nyt. Nu er det Foraar; jeg er frisk og fuld af Mod og Haab, men end er det ej Foraar i mit Hjerte.

19. 4. 1865 (G.): Idag har Vejbakkerne og Kragelunderne veret $\mathrm{i}$ Forhọr i Adressesagen. Indsterningen lod forskelligt efter de forskellige Grader. Adressen blev forelaest af Herredsfogden. Nielsen sjorde den til sin og forsvarede den Punkt for Punkt: »Hvad de trues med fra tysk Side $i$ Adressen? Niclsen viste først, at der intet Forbud mod Adressen forelaa, og at 
Politi og Gendarmer havde vidst længe om den Sag uden at forbyde den; derfor ansaa de det ikke for ulovligt at underskrive. En anden Sag havde det varet, dersom Militarmagten her ligesom i Aabenraa havde forbudt i hvert Hus at befatte sig dermed; men dette var ikke sket. »Forresten trues vi Nordslesvigere med Tilintetgørelse af vor Nationalitet og vort Sprog, og for at nævne noget materielt: vi trues med Optagelse i den tyske Toldforening; selv Slesvigholstenerne er derimod. Adressens "voldsomme Agitationer, der begunstiges fra oven « -. Nielsen nævnede eksempelvis: Vinduer indslaaes for at tvinge Folk til at vise et andet Sind, end de besidder, Skilte med Dansk eller med Dansk og Tysk gøres helt tyske i Flensborg, Aabenraa (og Haderslev, f $\varnothing$ jede Herredsfogden selv til). Den frie danske Menighed $i$ Flenshorg, et frit kristeligt Samfund, er sprængt ved Magtsprog. Dommen lød for Nielsens Person paa 10 Dages Fængsel paa Vand og Brød »für Schmähungen der Obrigkeit «, hvilket refererer sig til »voldsomme Agitationer fra oven «. De andre fra Vejbæk dømtes: 5 til 2 Specier Mulkt, 5 til 1 Specie, 1 til 4 Specier. Denne sidste var Bjørn Lorenzen fra Frydendal Kro, whan matte anses for mere politisk og verdenskyndig end de andre«.

2i. 4. 1865 (G. og M.): Biskop Boesen rejser imorgen, idag rejste Bispinden og 2 Døtre; Christian er hjemme, jeg skal op og sige Farvel. lgaar var her en stor Deputation fra Norden (Flenshorg med) paa 22 Personer med en Beschwerde [Klageskrivelse] til Regeringen; den blev dobbelt afskrevet i mit Hus af Werner og Thomsen, Harreslev. Det tog 4 Timer, saa lang er den, og hver Satning indeholdt nok til at komme i Hullet for; det er det kraftigste, jeg nogensinde har set. (Efterretningen maa ikke komme i Avisen!) Om nogle Dage kommer Dyret om muligt i Cölnische Zeitung og Fædrelandet. Kryger, Amorsen. Jens Janniksen (Skærbæk), Boisen (Tønning) osv., lutter graahærdede Mænd, vor Noblesse fra Norden. Gendarmeriet karakteriseres saaledes: »die am meisten demoralisirte und demoralisirende Institution, die hauptsächlich aus Überläufern besteht «, [den mest demoraliserede og demoraliserende Institution, som hovedsagelig bestaar af Overlobere osv. 


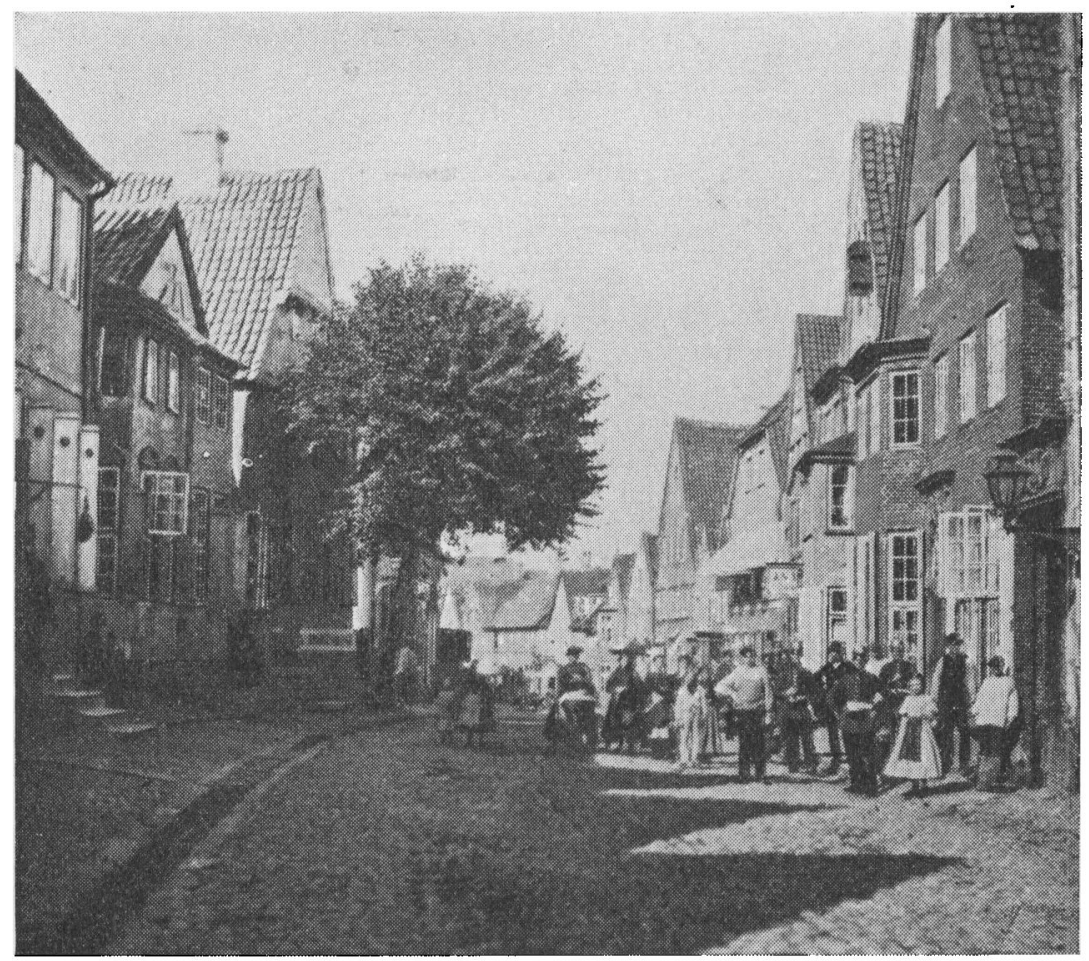

Norregade omkring 1865.

5. 5. $1865(G . o g M$.$) : Idag var jeg oppe at tale Tysk med$ [Borgmester] Bremer: »Gagen var os ikke udbetalt i forrige Maaned, var nærved at sulte ihjel«. Resultatet er: Skolen tørr de ikke ophæve.

14. 5. 1865 (G. og M.): I Marts indstillede Visitatoriet til Regeringen i Slesvig, at de danske Skoler uden videre skulde lukkes, Lærerne bortjages uden Pension eller Vartpenge. Derpaa har nu Regeringen svaret, at dette ikke kunde ske, da de danske Skoler var anerkendte Skoler; men der skulde anstilles en Unders $\emptyset$ gelse om, hvormange national-danske B $\emptyset \mathrm{rn}$, der bes $\varnothing$ gte Skolen, og hvormange slesvigskf $\phi d t e$, for at de sidste kunde f $\phi$ res tilbage i de slesvigske Skoler, medens de danskf $\varnothing$ dte blev gaaende 
i vor Skole. De overflodige Larere skulde da enten have Vartpenge, Pension, eller der skulde ses, hrormange der kunde anventes i de tyske Skoler. Saadan siger Reseriptet, som jeg naturligvis ikke har set, men hvis Indhold er mig fuldkommen rigtigt meddelt. Igaar blev Chr. Nielsen, Byfoged i Vejbak, Peter Thomsen, Byfoged paa Kragelund Mark, Joh. Moller, Byfoged i Harreslev, afsatte paa Grund af, at de havde underskrevet Adressen.

Endnu maa fojes til det forrige : de danske Bøger i Bov Sognebibliotek er indfordrede til Prastegaarden, Biblioteket skulde revideres; men derved er Bøgerne ligefrem lagte under Beslag, da naturligvis ingen vil gaa til den arrige Tysker og laane danske B $\phi$ ger. Det ved han jo meget godt. Præsten handler vist efter hojere Ordre; thi Superintendenten (Godt ${ }^{42}$ ) snapper hver dansk Kog, han kan faa Fingre paa ved Visitatserne, i Bibliotekerne eller paa anden Maade, kaster dem bag i Vognen; han har nok faat sig et Udvalg af danske Skrifter paa denne Maade. Latinskolelærer Lübker sø̧rger ogsaa for, at de danske B $\phi g e r$ forsvinder i Biblioteket paa Latinskolen.

Er der ikke en Maade at faa en Sending gode danske B $\phi$ ger herover til Vejbæk? De kunde sendes med en Skipper til Thomas Andresen, Brevet til mig, saa skal jeg nok sørge for Resten.

28. 5. 1865 (M. og G.): Har sendt Fortegnelse over 449 B $\phi \mathbf{r n}$. En hel Maaned vundet. Imidlertid skal der i disse fjorten Dage afgaa en Deputation til Zedlitz med Bøn om Menighedens Genoprettelse, og Skolens Forhold droftes samtidig paa den mest graverende Maade for Augustenborgerne Volquards, Bremer, Funcke etc. Der er jo Stof nok. Vinden er lige imod Augustenborgerne, den maa benyttes. Iaftes og i Dag har jeg faaet en udmærket Bagdør til Zedlitz, hvorigennem jeg er istand til at sende det allermest graverende, der ikke kan komme i Deputationens B $\phi$ nskrift. Han skal faa det to Dase i Forvejen. Var der dog en Mand,

42) Biskop Godt faar en meget udforlig Omtale i Carsten Jensen Petersen: >Slesvigske Præster (1938). S. 169 citeres en Sætning af Godts Brev til Provst Göttig 22. 10. 1864: ,Jeg stakkels Mand sidder saadan $i$ det, at jeg ikke ved, hvor mit Hoved er *. 
der vilde drage (Omsorg for al organisere en Slags dansk Wühlerparti herovre, i det mindste give et Program, saa kunde vi nok selv. Man ved ikke f. Eks., om det er Regeringen behageligt, at der arbejdes i Sydslesvig osv. (Hvad onsker den?) Der er en vid Mark. Idag har jeg aftalt med en Mand, at han i de blandede Distrikter skal se at rejse nogle Petitioner om Dansk i Skolerne. Der kunde gøres meget, blot Organisation! Nu har jeg Bekendtskab til Mand i Sydslesvigs, i $\emptyset_{\text {st }}$ og Vest, til de mest forvovne Gutter. Men man er mig for polsk i Kongeriget, arme Land! Var dette Valgvrøvl bare forbi! Raad og Penge, Penge og Organisation, det forstaar Preusserne bedre. Hilsen P.

29.5.1865 ( $M . o g G$.$) : Haabet vokser i København; det er godt;$ men jeg tror, man ikke kender Preusserne, man er vist lettroende; det kommer vist ikke saa snart. Var her Plan og Orden i dansik Agitation, da kunde det meste af Flensborg vindes for Danmark; men det er der ikke, det gaar kun saaledes, at hver arbejder efter sit Hoved. Forresten sover vi ikke let hen, men vi er ogsaa af dansk $\mathbb{E t}$, lettroende; alle Syner, alle nok saa urimelige Rygter tros; skuffes vi,tror vi paa et nyt Rygte, og saa fort videre. Nu har jeg faaet graa Haar, kan De vel nok hore paa Sproget, vil aldrig mere vaere lettroende, men det er det dog: Naturam furca pellas ex. ${ }^{43}$ )

I Afskrift findes vedlagt et Andragende fra danske Menishedsmedlemmer i Flensborg til Civilkommissionen, i hvilket der søres opmarksom paa, at den danske Menighed endnu 1864, efter at saa mange Familier - tvungne af de nye Forhold havde forladt Flensborg, talte over 400 Familier. I 1863, det sidste Aar, hvor Menigheden bestod uforstyrret, blev der endnu inden for Menigheden d $\phi b t$ mere end $100 \mathrm{~B} \phi \mathrm{rn}$, og 1864, da dens Forhold var meget forstyrrede, var Tallet mellem $80 \mathrm{og} 90$. Konfirmerede blev 1864 over 50 Børn, i 1865 endnu nogle og 40. Som Gennemsnit i de sidste 5 Aar fødtes 97, konfirmeredes 46. Menighedens Skoler besøgtes imod Slutningen af 1864 af hen-

43) Driv Naturen ud med en Høtyv; den kommer dog løbende igen (Citat fra Horats satirer\& I, 10, 24). 
imod 500 B $\not$ rn, endda paa Trods af de ugunstige Forhold. Thi under hele Krigen benyttedes Skolernes Lokaler til Lazaret osv., og endnu efter dens Ophør anviste Magistraten den ene Skolelygning med 3 Klasseværelser til militært Skrædderværksted, og derfor maatte Skoleb $\phi$ rnene indtil Slutningen af Januar i Aar anbringes i 2 middelmaadige Værelser. Saaledes kunde igennem tre Fjerdingaar enhver Afdeling Børn kun faa to Timers daglig Undervisning. Men ogsaa under saa ugunstige Forhold har der vist sig en saa stark Trang til disse Skoler, at de endnu i dette $\emptyset$ jeblik bes $\phi$ ges af ca. 450 B $\phi r n$. Ligesaa godt som Skolerne er besøgte, er ogsaa Kirken det hver S $\phi$ ndag, undertiden, f. Eks. endnu de sidste Pinsedage saa godt, at Kirken ikke kunde rumme 'Tilhørerne.

Disse Tal og Kendsgerninger vil mere end en almindelig Betragtning vise den store Trang, der foreligger til en selvstændig dansk Menighed i Flensborg med de nodvendige Skoler, en dystig Sjælesørger osv.

Men Trangen fremgaar ogsaa med Nødvendighed af de almindelige Forhold; til Dels har Flensborg alle Dage haft en betydelig dansktalende Befolkningsdel, dels omgives Byen paa alle Sider af delvis eller helt dansktalende Egne, og som stor næringsdrivende By trækker den uafbrudt fra alle Landets Dele nye Elementer til sig. Paa denne Maade fornyes uoph $\phi$ rlig $i$ Flensborg en Befolkning, som har dyb Trang til dansk Skoleundervisning og dansk Gudstjeneste, og uden denne Trangs Tilfredsstillelse maatte denne Befolkning for st $\phi$ rste Delen aandelig forkomme.

Indtil Slutningen af dette Aar havde Menigheden to Præster (en Sognepræst og en Kateket). Senere har man maattet nojes dels med en ung Kandidat, som efter nogle Maaneders Forl $\phi b$ forflyttedes til et andet Embede, dels med Vakanceprædikener. Hvormeget vore Kirke- og Skoleanliggender maa lide under en saadan Tilstand, ligger klart for Dagen.

I laengere Tid er vor Stilling altsala den, at vi ganske vist kan høre en dansk Prædiken og faa udf $\varnothing$ rt vore kirkelige Handlinger paa Dansk. Men vi har ingen Sjaelesфrger, til hvem de mange, som kun forstaar en Forkyndelse af Guds Ord paa Dansk, natur- 
ligt kan holde sig, og som kan paatage sig Sjælesorgen i Husene ved Sygdom og ellers. Thi vor Præst er netop kun Prædikant og kan ikke engang optræde frit som Sjalesørger.

De kirkelige Handlinger, som udføres i den danske Menighed, indføres kun $\mathrm{i}$ en tysk Menigheds Kirkebøger, og naar vi skal have udstedt Daabsattester o. l., maa vi henvende os til en tysk Prast. Ogsaa vore tidligere Kirkebøger har vi maattet aflevere til en tysk Menighed. Naar dertil kommer, at den danske Prast Iønnes med en saa ovenud ringe Gage (800 Mk. Courant aarligt), at en Familiefader umuligt kan leve deraf, og at vi saaledes ikke har mindste Udsigt til nogensinde at faa andet end ganske unge Mænd til Præst, som kun vil blive i Embedet en ganske kort Tid og sikkert fra forste Fard vil strabe efter saa snart som muligt at komme til en bedre Stilling, vil det sikkert være indlysende, hvor bedrøvelig vor Stilling er. Derfor tillader vi os at rette den ligesaa indtrængende som underdanige $B \phi n$ til den h $\phi j e$ Civilkommission;

1) At der isen dannes en selvstandig dansk Menighed i Flensborg, og at enhver, som fọler Trang dertil, faar Lov at indtrade i den.

2) At denne Menighed forsynes med et tilstrakkeligt Antal Skoler.

3) At Medlemmerne af den nyoprettede Menighed faar lige saa stor Indflydelse paa Valget af deres Sjales $\phi$ rger, som tilkommer de andre Bymenigheder.

4) At Sjalesørgeren lønnes paa en saadan Maade, at der kan være Udsigt til at faa en aldre dygtig Mand, som i det mindste kan blive laengere Tid hos os. Vi indestaar for, at Menighedens Medlemmer med Glade vilde bære alle nødvendige pekuniære Ofre, som en saadan Ordning vilde krave.

Vi tillader os endnu at tilf $\phi j e$, at vi er overbeviste om, at vi let kunde skaffe Hundreder af Underskrifter paa dette Andragende, dersom den høje Civilkommission matte $\phi$ nske at blive mere overbevist om den dybe foreliggende Trang. Vi har imidlerlid villet undgaa alt, hvad der kunde se ud som en Slags Agitation og forelagger derfor Civilkommissionen - kun i fuld Tillid 
til dens Retfærdighedsf $\varnothing$ lelse og Humanitet -- en Sag, som drejer sig om vore helligste Interesser.

Flensborg, den 10. Juni 1865.

Underdanigst: Zedeler. Monrad. (Th. Andresen kom for sent til Jernbanen). Jakobsen, Uhrmager. Sievecke, Skrædermester. Feddersen, Købmand. Bird, Konsul. Petersen, Cigarmager og Husejer (bag Møllen).

Paa Afskriften har Tofte tilføjet: »Om Menigheden vilde Zedlitz ikke høre, men om Skolen. Fik at vide, at nærværende var overleveret til Prinsen af Hohenlohe ${ }^{44}$ ) i Afskrift ... P.

22. 6. 1865 (G.). Skolen har hidtil staaet under en højere Magt, og hele Sagen, hvor sørgelig den end ser ud, staar ogsaa i Herrens Haand; der kan komme mere godt ud deraf, end vi tror. Preusserne - imod deres Vilje - maa hjælpe til det godes Sejr. Der er ellers Garing allevegne, og Sandhed begynder allerede at løfte Hovedet. Den sejrer nok til sidst. Naar Skolen blot Inaa staa, blaeser jeg dem et Stykke, om jeg ogsaa skal tage Kræmmerposen; men vi vil se. Werner og andre skal nok holde sammen. - Tanken holder sig ellers ikke lange ved samme Genstand; snart denne, snart hin Idé løber igennem Hovedet. For $\emptyset$ jeblikket grubler jeg over, har ogsaa allerede talt med tre à fire derom, at det var $\phi$ nskeligt at skaffe Bevis for, at Regeringen har handlet rigtigt $i$ de blandede Distrikter og tillige derved skaffe et Holdepunkt for Regeringens Handlemaade i Fremtiden. (Det staar fast hos mig, at Slesvig maa komme tilbage om kortere eller længere Tid, ellers var Tanken unyttig.) Saaledes er Tanken : P. staar udenfor og bagved. Med to Sydslesvigere, én Flensborger har jeg aftalt, at vi om ikke lang tid vil se at faa en Adresse i Gang - sogne- eller byvis - om at faa Dansk indført işen i Skolerne og Kirkerne helt eller delvis. Tanken er dristigs, nuligvis kan den ikke udføres, maaske gaar det dog. I Thumby kan det gaa; i Adelby mener jeg ogsaa; i Grumtofte ligesaa. Der

44) Denne besøgte i 1865 Flensborg og andre Byer for at forhandle med de danske Førere om Klagerne over det nye Regimente. (Mackeprang S. 12 f.) 
skulde jo 50 eller 100 i det mindste under hver Adresse. Til den Ende vil jeg bede Dem,dog uden at sige til hvad Brug, at bede Provst [Aleth] H.[anden] sige og skrive Dem op ved Hjælp af Embedsmændene derovre Navnene paa to à tre Mæend fra hvert Sogn (eller By) i de blandede Distrikter, til hvem man trøstigt kunne henvende sig. Ret snart. Det er nogle Brande, de tre, jeg har med at g $\phi$ re. Efter min Mening er det nu Tiden at erobre Slesvig moralsk; er dette sket, kommer det andet vel ogsaa.

Efter telegrafisk at have bedt om, at ovennevnte Brev ikke blev offentliggjort, hedder det i t Brev af 23.6.1865 (G.): Det

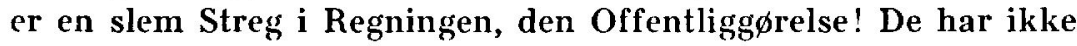
forstaaet Vinket, det var til Arkivet. Jeg er nu kompromitteret, Underskriverne er kompromitterede. De kan tro, jeg fik en drøj Tur i Aftes med Monrad osv. Kunde De nu bare forhindre dens Optagelse i Berlingske og Dagbladet ligesom og al Tyggen Drøv derpaa i Aviserne, saa gjorde De Sagen og os en god Tjeneste. Det er ikke let at være $\mathrm{i}$ Fjendehaand og saa saadan komme i Bladene. Sagen er jo den: Der er endnu intet naaet, det skal forst komme, men man mener nu, det kommer ikke. Hvorom alting er, forhindrer saameget som muligt al videre Omtale heraf. Aktstykket er forresten godt, og jeg er ikke sky for Skrald, men fra den Side havde jeg ikke ventet det, idet jeg stolede aldeles paa Deres Forsigtighed. Underskriverne er naturligvis vrede paa mig og Dem; det giver sig nok; kanske det dog kunde vare til Nytte; men det ses endnu ikke.

(Søndag Juni: 1865 (G. og $M$. ): De ser jo vel, at vi slaas endnu paa Liv og $D \phi d$, - og haaber jeg, vi med nogle Smaapust lian holde ud en Stund. Slagteren (saa vidt jeg ved) har endnu ikke faaet Listens Historie; han arbejder vel trøstig paa den danske Skoles Ruin. Der kampes rundt omkring Flensborg, i Syd og Nord, snart saa og snart saa, og hvad det er for en Kamp, og hvorfor man kæmper, det fremgaar blandt andet ogsaa af det sadvanlige Sp $\phi$ rgsmaal af vedkommende, naar en eller anden Sejr kroner Kampen: „Hvad siger de saa derom i Kohenhavn, hvad siger de i Danmark om os, hvad siger han eller han? osv.«. 
Det er glædeligt og r $\varnothing$ rende at se, man f $\varnothing$ rer Kampen stadigen med Maalet for $\emptyset_{j e}$, men alligevel med Kæmperes sædvanlige Haab: Ros, Berømmelse.

17. 8. 1865 (G. og M.): Overpolitiet havde været to Gange paa Hjemkomstdagen - ['Tofte havde været paa en Ferierejse til København] - og spurgt om mig, da jeg skulde i Forh $\phi r$; man havde underrettet Politiet om, at jeg maaske kom hjem med Dampskibet. Politiet var naturligvis tilstede ved Landgangen, Th. [omsen], W. [erner] og flere ligeledes. Det var ret morsomt at se de bekymrede, alvorlige Ansigter, disse Venner satte op; jeg kunde nok se, det angik mig, men vidste ikke hvorledes. Man ventede nemlig, at Betjentene lige ved Landgangen vilde snappe mig; jeg derimod troede, min Kone var syg, hvilket mine Smaas glade Ansigter vidnede imod. Rolig var jeg, men dog fattet paa adskilligt, hvoraf intet indtraf, da Politiet havde ladet mig med Fred indtil Dato. Forh $\varnothing$ ret vil nok komme, det gælder Afskrivningen af de Syttens Adresse og har ikke noget paa sig. Man mindes straks om at have Tand for Tunge og et $\emptyset$ je paa hver Finger. Boi [Boy Jensen] havde samme Dag stukket Dannebroge ud for at hilse paa Md. Rasch's Skonnert, der kom os imod. Skolen staar endnu, jeg tror den bliver staaende; jeg har søgt Underretning om den rundt omkring. Sagen drives ikke med Kraft, jeg tror ikke, at man $t \varnothing \mid r$ det. Komme, hvad der komme vil, den Gamle lever endnu. Nu er jeg styrket og kan nok taale et Stød.

\section{8.1865 (G. og M.): Her en sandfærdig Beretning:}

Fredag, 4. Aug. 65: Visitats i Adelby Skole og Kirke.

Strax da Provsten ${ }^{45}$ ) var kommen ind i Skolen, spurgte han Degn Schlesinger og senere ogsaa de andre Larere, hvor langt Børnene vare komne i det tyske Sprog, om det danske Sprog hindrede det tyske Sprogs Fremgang, om B $\varnothing$ rnene nok viste Lyst til at lære det. Da Børnene havde last, talte Provsten saaledes til

45) Prasten ved St. Johannes, H. A. F. C. Volpuardts var Provst 20. 2. 1865 til sin I) gd 23. 11. 1866; han aflostes af Peters som fast ansat Provst. 
dem: »Med Læsningen kan jeg ikke være tilfreds, da det smager efter det Danske. Naar I f. Ex. sige Ordet $\gg$ Vater \&, saa udtaler I A'et ikke rigtigt, thi I maa ikke sige »aa (a) eller »a« saaledes, som Danskerne udtaler det.s — Saa fortalte han Børnene, hvorledes de skulde bære sig ad med Udtalelsen af dette og af 1lere Bogstaver. Efter endt Katekisation spurgte han B $\phi$ rnene, hvad for et Sprog de talte hjemme, om det var Tysk eller Dansk. Intet Svar. »Naa, I taler vel Tysk, ikkesandt? « Nogle B $\phi$ rn svarede svagt derpaa: $\gg$ Ja! « Derpaa fortsatte Provsten: $\gg$ Ja, Drenge, lukker nu Eders tyske Øren op og kaster det danske Kram zum Fenster hinaus; thi nu har I igen Eders tyske Modersmaal, hvorfor I maa takke den kare Gud. Det danske Sprog horer slet ikke hjemme her, det har hjemme højt oppe imod Nord; men vi, vi skal se imod Syd og ikke imod Nord, hvor vi ikke hører hjemme. Derfra kommer heller ikke andet end Skarn, der forpester Luften; dog, nu kan vi være fuldkommen rolige, da det ikke kan komme ned til os, thi nu er vi igen tyske, som vi var før. - Men hфrer B $\phi r n$ ! jeg hører, at I ikke vil hilse Eders Præst og Lærere, og jeg hører endogsaa, at I i Stedet for at bevise dem Ere og Agtelse forhaaner og bespotter dem, det kan og skal ikke saaledes blive ved, og naar jeg moder én af Jer paa Gaden, og naar jeg ser, at I ikke hilser, saa tager jeg denne min højre Haand og slaar Eder »den Deckel vom Kopfe» [Huen af Hovedet]. Saa gik man ind i Kirken, hvor Præsten Hoeck holdt en Tale. Efter Prædiken gik Provsten ud i Kirkegangen og sagde, at han $i$ lang Tid ikke havde hort en Prædiken saa skøn som denne, og at han havde haft meget godt deraf. Saa begyndte han af alle Kræfter at gaa frem og tilbage, slaa op og ned, frem og tilbage med Hænderne og holdt samtidig en Tale, hvoraf kun det halve kunde forstaas, da han i sin overvættes Hidsighed og Frgrelse næppe kunde frembringe Ordene. Her er det, der lunde høres og forstaas: »Røvere og Kirkeskændere har varet her og talt til os i fremmede Sprog; men nu, nu da vi Gud ske Lov har overstaaet denne Tid, da vi har faaet vort Modersmaal igen, og nu, paa en saa vigtig Dag som denne, nu kan Adelby Menighed ikke engang komme til Guds Hus. Kan Du ikke forstaa, Adelby, hvad Gud i sin Naade har gjort for dig? Hor tit og 
mange Gange ${ }^{46}$ ) har jeg ikke f $\phi r$ staact her foran Alteret og paa Irædikestolen og har talt Guds Ord til dig; men dengang var der ogsaa mange, der ikke besøgte Guds Hus. I denne Prøvelsens Tid, i disse lange 17 Aar, i hvilke jeg nu har varet borte, efter denne Straffetid, skulde man dog tro, at I var bleven bedre, men nej, tværtimod, det er bleven varre og værre - nu er I lig Hedningerne, især dem fra Norre St. Jørgen og fra Nørre Hulvej, men vi skal nok omvende eder. Har du nu forstaaet mig, Adelby? For sytten Aar siden saa man dog aarlig forsamle sis henved 2000 Mennesker for at nyde den hellige Nadver; men nu, da Menigheden har forstørret sig saare, nu er der desværre næppe 200. Hvad skal det blive til, Adelby? I fra Norre St. Jorgen og I fra Nørre Hulvej, hvor er I? I Mænd, Kvinder og Børn, hvor er I? Børnene er her, de skal jo møde; dersom de havde deres frie Vilje, saa blev de vist ogsaa borte. Mange Bekendte og mange gamle Venner har jeg her, men ikke en af dem er kommen for at hilse paa mig efter den lange Fraværelse; ja, visseligen, det skærer mig dybt i mit Hjerte, naar jeg tænker derpaa.« -

Saavidt Talen. Saa snart Drengene fra St. Jørgensby var komne ud paa Vejen, sagde de: »Vi bryder os Fanden om denne gamle Karl og hans Politik, og saa sang de: »Dengang jeg drog afsted helt ind til Jørgensby, Drengene fra Hulvejen sang: ¿Freidigt kan Du stande.« -

30. 10. $1865(M, \circ g$ G.): Den 24. Okt. indgav jeg Andragende til Skoleinspektionen om, at der snarest muligt maatte blive sørget for Brændsel til vore 4 Skolestuer i Graven, da vi til 1. Novbr. astede at begynde med Ild i Kakkelovnen. Mit Andragende havde en ret morsom Skabne, det blev foredraget for Volquardts og Funke paa Md. Rasch's Stentrappe af Slagteren, til hvem jeg imod Sædvane sendte det, istedetfor til Carstens. Volquardts svarede: »Nej, Brandsel skal de ikke have fra os«. Funke: »Det er jeg indforstaact med «. Det var nu efter Forventning, Svar har jeg ikke faaet endnu. Men det morsomste ved Sagen er den Maade, hvorpaa jeg har faaet dette at vide. Fanny Mattesen var

46) Inden Volquardts i 1850 afskedigedes af Danskerne, havde han fra 1840 været Provst i Flensborg. 
syg den Dag, Manteuffel ${ }^{47}$ ) kaldte Embedsmændene til Audiens hos sig i R.'s Hotel; naturligvis maatte hun hen og se den Staahej og staar og opsnapper denne Samtale om den danske Skole. Smaa Gryder har ogsaa Øren. Dette har rigtig godtet mig; men jeg faar vel se paa en eller anden Maade at skaffe Ild. Gage endnu ikke i 7 Maaneder, Ild heller ikke; Skolens Historie bliver nu interessantere end f $\phi$ r. Vor Præst er jeg hjertensglad ved, Menigheden ogsaa, og vi har god Grund dertil; han er den, der er bedst skikket til denne Plads for $\emptyset$ jeblikket; men Vorherre har ogsaa sin Haand med heri. Der rører sig meget Godt i Jørgensen, ${ }^{48}$ ) hans Prædikener er meget opbyggelige og Menigheden vil efterhaanden komme til at holde meget af ham ligesom jeg. Han vil med al sin Kraft virke for Sagen; dette b $\phi \mathbf{r}$ nu ikke just omtales; men jeg takker Gud for ham. Gid de dog snart maatte blive enige derovre i Kongeriget.

1. 11.1865 (G.): Nyt er der intet af, undtagen det, at Freudenreich, Th. Andresen og Uhrm. Jakobsen paa Fredag rejser til Zedlitz om Skolen igen. Jens har i Dag lært sin f $\phi$ rste Lektie Latin med Pastor Jørgensen, som ogsaa læser Verdenshistorie med ham. Gud ske Lov for den Præst, saadan noget er det bedre at overlade til Vorherre end selv frembringe; jeg mener, han er maaske bedre skikket for Øjeblikket, end Krog vilde være; men jeg har sagt ham, at han ikke en Uge faar Lov at være her, efter at Dansken er rykket ind, saa skal Graae være Præst, ham skal jeg fors $\varnothing$ rge med et godt Embede et andet Sted. Der er kommen hertil 19 Dekorationer ${ }^{48}$ ) til Damerne, der passede de Saarede, samt egenhændige Skrivelser fra Kongen.

17. 1.1866 (G.): Har man f $\phi r$ rst faaet Smag paa de Dele, saa leelmer man ikke, før man ikke kan mere. Oplysning maa frem-

47) Den nye Guvernør for Slesvig, General E. v. Manteuffel, afviste ved sit Bes $\varnothing \mathrm{g}$ i Flensborg den 26. 9. 1865 enhver Tanke om den mindste Landafstaaelse i Nordslesvig (Haandbog S. 596).

48) Ang. Pastor Jørgensen se min Artikel i „Grænsevagten «, Jan. 1932.

40) Broscher med Dannebrogssløjfer og med Indskrift „Adel Daad glemmes ej« (Haandbog S. 623). 
mes i enhver Retning, det f $\varnothing$ ler jeg, og det stræber jeg efter, dog mest i Dansk. Julen har i den Henseende været rig paa Velsignelser; tænk bare, gennem mine Hænder er der udkastet blandt Befolkningen ca. 1000 Bind danske Skrifter i den Tid, og hvad der glæder mig meget, Ploug lovede mig 6 Eks. af »Fædrelandet « i Sommer og har nu gjort det muligt. Dette gaar saaledes til (det er kun sagt til Dem) : Folk i Odense betaler for 6 Eks., 6 forskellige Mænd her bestiller og betaler Bladet, men Pengene bliver dem siden betalte, altsaa læser de gratis. Mændene har jeg fundet, de er: en i Broager, en i Vejbæk, Harreslev, Hanved, Flensborg, Angel. Det var den Ting. Kunde der nu ikke virkes paa lignende Maade for, at $\gg$ Berlingeren $*$ blev udbredt her, den var næsten bedre Folkelæsning end Fædrelandet, i det mindste i Angel. Er der ikke en eller anden Forening, der vilde betale nogle Eks. deraf, kort, bære sig ad som Odenscanerne? Jeg ved ingen at henvende mig til i denne Sag, men beder Dem tænke derpaa, om De ikke kan finde en eller anden Udvej; Læsere skal jeg nok skaffe. I Flensborgs nærmeste Omegn er man taaleligt fors $\phi r g e t$, Angel og længere i Vest staar nu for Tur; jeg skal nok, om Gud vil, faa lidt Indpas der, naar jeg faar Midler i Hande. Kunde De hjælpe mig til disse, saa vilde De gøre mig glad. Den Tid kommer nok, da Udsæden vil bære Frugt. Skolen har stor Indflydelse paa Byen. Jeg tanker tit, at det var en heldig Tanke, at De byggede den paa Frihed. Frihed har sejret $i$ dette Stykke indtil Dato, trods alle Angreb og Drillerier. Slagteren siger nu aabenbart til alle, at det er den bedste Skole i Byen; han vil skade os derved, men gavner tværtimod. Vor sidste Eksamen (Visitats) gaar der blandt Børnenes Foraldre meget Ry af. Det hjalper ogsaa.

6. 2. 1866: Nu vil der forresten blive Mangel paa danske Skrifter. Der er nemlig oprettet en Landboforening..50) Biblio-

sn) sandboforeningen for Flensborg og Omegn oprettedes 0 . 1. Okt. 1865 ved et Møde hos Vinhandler Colding. Den 28, 1. 1866 veditoges Vedtagterne og valgtes Bestyrelsen. Formand: Chr. Nielsen, Vejbak; Nastformand: Apotheker Winsted paa Aagaard; Bogfyrer: Carsten Thomsen, Frøslev, og Regnskabsfører P. Rossen, Fr $\phi$ slev. 
thekar skal Toft vare, og P. skal hjalpe. Til Foreningens Medlemmer rundt om Flensborg skal stadig cirkulere passende Bøner. Der er ogsaa paatænkt paa Landet at oprette flere Vinterhondeskoler efter en mindre Matalestok. Det er gliedelige Tegn; vi ruster os til Modstand.

27. 2. 1866: I Tredskov var der forrige Uge Eksamen. Præsten

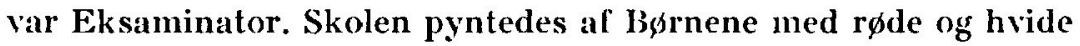
Baand, som Lareren for $\phi$ gede med et blaat. En Kone fra Byen saar ind og tager det blaa Baand bort, Læreren vil have det, men kan ikke magte Konen. De to Farver bliver altsaa eneherskende. Efter endt Eksamen siger Præsten: $\gg$ Nu kan vi synge $\gg$ SchleswigHolstein «. Intet Barn rører sig. Lareren befaler tre Gange ude

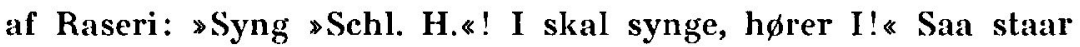
en Dreng op, vender sig om til de andre Børn og siger: »Ja, skal vi synge Schleswig-Holstein, saa maa det være »Slesvig-Holstens falske Sønner, I har brudt Jer Troskabs Ed\&, for andre kender vi ikke her «! Læreren rasende. Præsten :»Ja, Saa kan det være det samme.« Børnene har nu faaet et helt Læs danske Bøger ud, de er det sandelig værd. Alt foranstaaende er Kendsgerning.

12. 3. 1866 (M.): - - Rygtet gaar i Dag saaledes: Preussen har spurgt Danmark, om det $i$ en eventuel Krig vilde holde sig neutralt, naar det fik Slesvig tilbage. Kongen har da svaret, han turde ikke stole paa preussiske Løfter. Det var det. - _ -

12. 4. 1866: Egentlig har jeg i længere Tid villet skrive et rigtigt Brev om vore Sager her, men det har ikke villet gaa, og kanske gaar det heller ikke nu. Forsøges skal det dog. Altsaa: den 22. Marts blev Beboerne fra danske Distrikter, hvilke stadigvæk фnskede, at deres B $\phi$ rn skulde bes $\emptyset$ ge den danske Borgerskole, af Peters og Carstens som Skoleinspektion sammentrommede til Møde paa den danske Skole i Graven, for af en Slags Skolekommission at blive afhørte om Hjemstavn osv., senere skulde den endelige Bestemmelse tages; de fleste vejede var for lette. Carstens havde en daarlig Fod (!), mødte ikke. Peters, Formand, Sadelmager Maack (lutter Galde), Køhmand 
Splek, Sarhekoger IIansen (rolig Mand, Statist) udg.jorde TribuInalet. Det kan nok vare, der holdtes Forhør. Klokken 2 begyndtes; da det var mørkt, var man endnu ikke færdig, men det gjorde intet, Resten maatte gaa uafh $\phi \mathrm{rt}$; enhver, der havde B $\phi r n$ i Skolen, mødte og forfagtede sin Ret. Det er sikkert den svareste, men ogsaa den gladeste Dag i Slagterens Liv. Han maatte høre de drøjeste Sandheder, Støjen og Raabene fra Gangen og Trængselen er ikke til at beskrive. »Ihr sollt ruhig sein!« maatte Peters flere Gange raabe ud af Doren. Han modtoges med »Hurra, smid ham ud den Slagter!« Endelig sendte han Bud efter Politiet, men Budet holdtes indeklemt $\mathrm{i}$ Gangen $\mathrm{i}$ en hel Time. Siden kom Overpolitiet, der havde Takt nok til at foreholde P. det upassende $i$ at lade saadan en Masse Mennesker staa og vente flere Timer paa Trappen. Sommetider var Døren iklemt af Massen, saa ingen kunde komme ud; aabnedes den endeligt, valtede Ihan ind.

Enkelte Træk:

Købmand Knudsen fra Broen, Krabyes Efterf $\emptyset$ lger, kommer ind. Peters: \$Hvad vil De?« - K.: »Ligesom de andre«. P.: »De har jo ingen Børn«. — K.: »Dem jeg kan faa, dem vil jeg reservere en Plads. $\ll$

Tine Ravgal fra Fyrtaarnet siger til Flokken, inden hun gaar ind: Ik soll ihm Gott verdammig wisen, dat ik en beskidte Snut hev. Hende er $P$. bange for; hun fik, hrad hun vilde.

Paris ind. P.: »Hvor er De fra?« Paris: »Fra Berlin«. P. taber Pennen af Forbavselse. »Jeg taler Dansk med min Kone og mine Børn, de kan ikke Tysk «.

Tømmersvend Frederiksens Kone ind. P.: $₫$ Hor er De fra? „Fra Flensborg; ik vil min Kind in de Skoel behaalen«.

P.: »Det kan De ikke«. Md. Fr.: »Dat soll ik Sie G.v.dammi wisen. De kan jage hende bort, hun skal stadigt komme igen Maack indblander sig og siger: »De har saadan en rar Mand, han kan nok tale Tysk«. Konen: »Haal he sin Snut, ik spreck nik to im. Men jeg veed nok, hvem der er Skyld i det Hele, det er Dem, Pastor P.! aber töv, bit et wedder omgeit«. Hun gik ud af Døren og sagde $h \emptyset j t: ~ \gg H e$ is so rot in sin Kop as en kogle Krebs«. Hun modtoges derude med et kraftigt Hurra. 
Der kgrtes ogsaa med svart Skyts. Uhrmager Jakobsen og Pelers havde en voldsom Batalje. Mange var tilstede, som ingen Børn havde, de var pludselig blevne Formyndere.

Peters trostede flere med, at om 2 Aar var der intet Dansk mere i Flensborg. Dette besvaredes der udefra med: „Om 2 Aar er

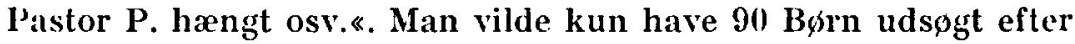
Hecepten »fra danske Distrikter«, men fik 200, der nu skal lied til 120, som skal undervises af Tofte og Hjælpelæerer i to Klasser. Rart Arbejde. Efter Turen paa Skolen gik flere op til Iolquardts og gennemheglede ham: men han svarede: »Jeg skal alle Tider være Djæevel; dengang er jeg det ikke, det er Peters ? Peters havde sagt til Tofte, at han Tirsdag, sidste Dag f $\varphi r$ Paaske, vilde komme og skille Faarene fra Bukkene; dette skete imidlertid ikke. Som jeg hører, havde Kirkebudet bragt Peters et Brev fra Volquardts, som havde givet Budet Ordre til at bringe det "hinab zu dem Kerl«. Saadan er Sagen, Skolen maatte gerne hlive staaende for Volquardts. Siden den Tid har aer varet en Deputation hos Manteuffel, der lovede, at Sagen skulde blive grundigt unders $\phi$ gt. Nu i disse Dage gaar der en Deputation til Djævelen fra hver Mand, der har Barn i Skolen, 30 Stykker hver Dag. Byen er inddelt i Distrikter. Man skriver efter otte à ni forskellige Copier. Det har givet noget at rode $i$; men jeg staar naturligvis uden for det hele. Hjælper dette nu ikke, saa skal der en Deputation til Berlin. I denne Virvarstid har det dog varet mig en Hjertestyrkning at se alle gaa paa med Lyst og Kraft for Dansk, dette er egentlig for mig Løn nok, hvad saa Resultatet bliver; det indeholder for mig en Spaadom om en Fremtid for Flensborg. Der kommer flere Foræringer til vort Alter fra Damer her. Til Kongens Fødselsdag fik vi et Brysseler Tappe at lagge for Alteret, senere kommer et dejligt Alterklaede.

23. 4. 1866 (M.): Byen er næsten i Oprør, den ene Kælling spørger mig til Raads efter den anden. »Gaa til Volquardts og Slagteren« — »Ich soll Gottverdammi em et sengen «. Saadan gik det hele Formiddagen, jeg var fuldkommen mør, matte retirere og er ikke hjemme hele Eftermiddagen; men nu or min Kone selv hjemme. Dóren er aldrig lukt. „Gaa til Peters og Vol- 
quardts! « er L $\phi$ senet, eflerat Instruksen er givet. Den ene Furie efter den anden sendes ham Jaa Halsen. Han har nu nasten laset nok. Til Pastor Jorgensen sagde han, at han var nastell $\phi$ delagt; til en Kalling sagde han: „Hvis det bliver saadan ved, maa jeg tage min Afsked". Hun kaldte ham en Jesuit, han gik $i$ Ctaalmodighed op og ned af Gulvet i det samme. En Kone besvimede hos ham, og han maatte hente Hoffmandsdraaber. En Kone: »Vi kender Dem nok, De slog i forrige Krig Vinduerne ind hos Pastor Valentiner med Deres Faders Tekedel. Havde vi ikke vaeret, var De ikke bleven valgt til Prast, men det var for Deres Faders Skyld; han kunde ikke svarge til tre forskellige Konger, saadan som somme kan, nej, det var en arlig Mand."1) Volquardts bad en Deputation idag, at de ikke en anden Gang skulde komme saa mange; han lover godt; vil se, hvad han kan gøre, vil have mere Dansk i Werners Skole, der er fire Timer om Ugen, vil tale med Manteuffel, vil hjalpe allevegne, kort, han kravlede gerne $\mathrm{i}$ et Musehul. Morgen osv. noget lignende; hvis det ikke hjælper, saa videre og tilsidst Privatskole.

Vi trænger til Lærere, f $\phi d t e$ her, som vil komme herover og hjalpe ved Oprettelsen af Bondeskoler for aldre B $\phi$ ndersønner; sig mig, hvem De har paa Deres Liste af ledige af den Art, navnlig saadanne, som har Lyst og Evne. Der kan tjenes derved og gavnes meget, synge skal man kunne. Helst Folk fra Landet.

2. 5. 1866: Illustreret Lysestage,, ${ }^{52}$ ) meget godt! Tak. Egentlig betragter jeg nu mig selv som unytlig Stridsmand her; det, jeg kxmpede for, er faldet. Det er kun lidet, der er bleven reddet. Ja, dersom Herren snart vilde sende Hjælpen, saa er det dog alletider noget. Hele naste Aars Konfirmandflok har faaet Lov at

51) Pastor Peters' Fader, Hartwig Peters, var fra 28. 9. 1825 til sin Død den 19. 9. 1848 Andenpræst ved Mariekirken. Ligesom Pastor Asschenfeldt ved St. Nikolaj og Pastor Holdt ved den danske Kirke forblev han loyal under Treaarskrigen ( Grænsevagten 1921-22, S. 266 og Darstellung derjenigen Charactere, welche in der Stadt Flensburg an unserer so ganz ohne Veranlassung hervorgerufenen Revolution thätigen Antheil genommen haben - von einem stillen Beobachter (Fl. 1850), S. 6).

32) I Randen med Regenburgs Haand: see Ill. Tid. Nr. 344, 1866«. 


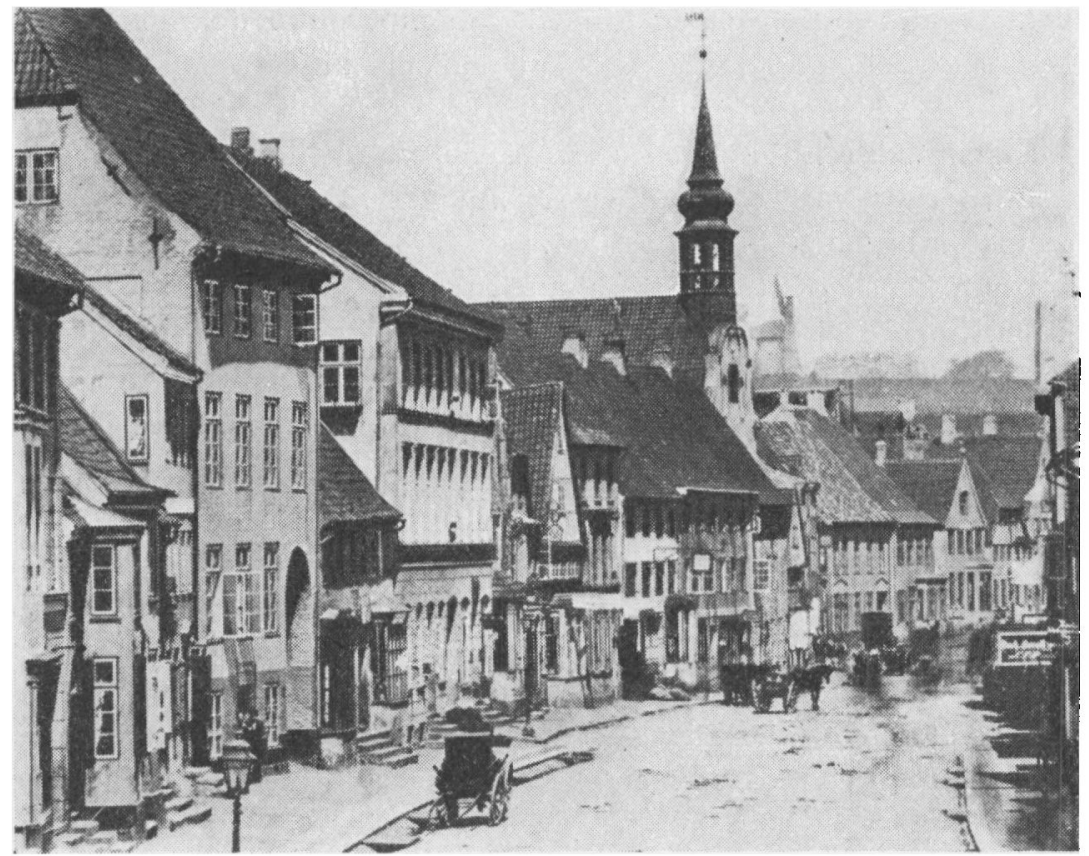

Storegade med Helligaandskirken omkring 1875.

blive. Skolen tæller alt i alt en 130 B $\varnothing r n$. Intet Barn faar mere Lov at blive optaget i Skolen, saa den er nødt til at ophøre af sig sclv. Nissen er min Hjælpelaerer, han er altsaa ogsaa forel $\phi b i g$ reddet.

Jeg bor nu paa Skolen i Muncks Lejlighed, Præsten i min. $\checkmark i$ er i Gang, men der kommer endnu stadig flere Born, end j'g maa have. Werner har næppe Halvparten af dem, han skulde have. Dette er korteligt Status. Jeg har ellers stadist, navnlig i den Tid, der gik forud for Skolens Opløsning, gaaet og kæmpet med en svær Frygt, ikke fordi jeg vel vidste, at den skulde falde, det var mig det Mindste: Lad falde, hvad ikke kan staa, men for hvorledes Faldet vilde blive. Nu er jeg trøstet og rolig i den Retning. Slutningen kunde vi ikke alene være bekendt, men endog stolte af. Jeg er stolt som en Sejrherre og hviler nu paa mine Laurbær. Sidste Kamp er ført, saa den burde genlyde $i$ 
hele Landet, hele Norden, saaledes kæmper kun de, der har en retfærdig Sag at kæmpe for. Jeg haaber, at den kan føres til Nytte, i det mindste giver den mig et Haab med Hensyn til Flensborgs Fremtid. Peters forfaltede en Liste over alle de enkelte B $\phi \mathbf{r n}$, der maatte optages i Skolen. Deri er gaaet frem med den stgrste Partiskhed. Skolen skulde være »for dansklalende 1ra danske Distrikter\&. Saa kom der til at gaa deri en Berliners B $\phi r n, B \phi r n$ af to kongerigske f $\phi d t e$ Forældre, B $\phi r n$ af en Nordslesviger og Flensborger osv., alle de Variationer, som kan tankes, medens andre af selv samme Aarsager udeluktes. Peters har brugt til sin Raadgiver og f $\varnothing$ rste Minister Stadsvagtmester Hansen Beck, der har gaact omkring og bestemt, hvem der talte dansk, hvem tysk. Det er markeiigt, men ganske tilforladeligt. Scenen paa Skolen var kun et Skin, medens Afgørelsen egentlig laa i den allerværste, mest underordnede Persons Hænder. Det var da ogsaa bestemt i Forvejen, at der skulde kun være to Lærere ved Skolen, derefter skal det saa passe; med et let Pennestrøg g $\varnothing$ res her tysktalende, det er preussisk, men Peters har jo ogsaa faaet en preussisk Orden, den fortjener han nu. Saa kom Dagen, at B $\varnothing$ rnene efter Hansen B.s Tilsigelse til hver enkelt skulde møde i Skolen, da fik dansk Skole 300, næste og de f $\varnothing 1-$ gende Dage ligesaa, medens tysk Skole fik 30 Stk.

Men saa begyndte Stormen, hver forurettet, og det var alle, der ikke fik sine Børn i dansk Skole, hen til Peters, Volquardts og Borgmester Bong-Schmidt, de belejrede formeligt deres $\mathrm{D} \phi \boldsymbol{r e}$ fra Morgen til Aften, og hvis vedkommendes Pine ikke havde været stor f $\phi r$, det blev den nu. Klager, Trusler, Bønner, Skænderi o. s. v. paa hvert Sted. Endnu kommer der flere hver Dag af den Art. Hvad dette har været for en Plage for Vedkommende, dette har jeg et svagt Begreb om, da de fleste i Forvejen kom til mig, naturligvis i al Venskabelighed, og jeg maatte høre paa deres Kæremaal; jeg var dødtræt; men hvad saa, naar der sprudedes Gift og Galde. Velbekomme! Jeg har nok skrevet om det før. Endnu gaar de fleste Børn til tysk Skole og driver, der hersker et umaadeligt Virvar. Peters inspicerede Werners Skole idag, fandt $1 / 2$ af, hvad der skulde være, men $\gg$ jeg skal nok lære dem at komme i Skole«. Vognsen har indgivet en Ans $\varnothing$ gning til Visi- 
tatoriet om Tilladelse til en Privatskole, men da han bad Peters om en Anbefaling, fik han det frokke Svar: »den var ikke nфdvendig, han vilde modarbejde den af alle Krafter, og han fik ingen Tilladelse.« Ansøgningen er gaaet ind. Saa vidt havde jeg ikke troet, han var. Idag er Freudenreich, Jacob Plaetner, Tanck lios Manteuffel paa Gottorp Slot. Dette er ifølge skriftlig Ordre: de skulde møde for at faa Besked paa deres Petition og alle de andre Petitioner. Svaret er ikke gunstigt, ellers havde jeg faart Telegram. Resultatet skal blive Dem meddelt siden, maaske i dette Brev. Man vil i det mindste holde paa at faa Tilladelse til Privatskole, dette nægtes vel ogsaa. Peters har sagt til flere: om 2-3 Aar skal der slet intet Dansk være i Flenshorg. Tænker han ikke paa Pengepungen, idet han siger saa?

Deputationen fik altsaa Svar af Manteuffel. Ansggningerne havde naturligvis været her til Bericht, i det mindste Deputationens; hvad Peters og Volquardts har berettet, kan man jo let tanke sig, og hvad Manteuffel har onsket til Svar, det har han let kunnet faa. Maaske har han sendt et Skema i den Anledning til Udfyldning. Manteuffels Svar er helt polsk. »De, Deput., havde løjet for ham i Indberetningen: de mange Ansøgninger, det var Agitation (hvert Ord i disse og i Deput., var naturligvis den rene Sandhed), han holdt ellers stift paa Nationaliteterne, men nu havde de tabt deres Sag for ham. Dermed kunde de gaa . Polens Skæbne bliver vor, hvis Hjælp ikke kommer. Saadan skal Sønderjyden behandles, saadan Nørrejyden o. s. v. Hvad Hundreder og atter Hundreder фnsker og har Ret til at forlange, det er Løgn, naar P. og M. vil have det dertil; men naar Dansk skal undertrykkes i et Sogn, da behøves kun højest tre Mand til Vidne paa, at det er nфdvendigt, saaledes i Harresløv; noget lignende er sket i en Del af Bov Sogn. Stakkels Flensborg, det er bestemt til Undergang i den og den Henseende, stakkels Danske heroppe, de skal med 'Tiden udslettes af Jorden ved Tyskernes Haand. Der er ingen Hjælp derimod uden ved at slutte os sammen saa mange, som er af nordisk Stamme. Danmark, Norge, Sverige maa og skal forenes! Hvor udtænkt Ondskaben el imod Deputationen kan man se af, at Manteuffel Dagen i Forvejen var her i Flenshorg, men alligevel citeredes Deputationen 
til Slesvig for at modtage Røflen. Dep. kom slet ikke til Orde, han vilde intet høre. Idag er Djævelen her i Byen igen. »Altsaa Løgn og Agitation er det hele«, sagde Manden til disse 3 troværdige, hæderlige Mænd. Betegnende er det ogsaa, at Volquardts laa syg, da Oplosningen foregik, han havde overgivet det i Peters Hander; del er ham alene, der er den rette Mand; jeg tror ikke, man har vovet at faa Volquardts til dette Stykke Slagterarbejde. Nu satter jeg mig til Ro og passer mil lille Vark, min Kaphest skal nu være at uddele dansk Laesning imod Syd, Vest og $\emptyset$ st, det gaar godt i den Henseende, men mange flere Bøger behøves endnu. Religiøse er isar passende i Angel, og man spørger efter saadanne. At Flensborg har kæupet paa Liv og Død for Dansk, dette er nu en historisk Kendsgerning og burde slaas fast i Europas Krøniker; men Hævnen for Voldsgerningen burde skrives paa Preussernes Ryg. Det er rart, at hele Varket er bygget paa Frihed.

6. 5. 1866: Fuldstændigg $\varnothing$ relse. Da Deputationen f $\varnothing$ rste Gang var hos Manteuffel, da den overrakte sin Petition, talede han i lutter søde Ord til den, om at han var retfordig mod Nationaliteterne, de var ham lige nær, men han kunde ikke gaa efter disse 3 Maends Ord, man maatte høre mere; saa kom alle de mange Petitioner, derover var han nu saa vred, det var Agitation. Han havde ellers gennemlæst alt, undersøgt Sagen nøje, indhentet Efterretning fra sin $\emptyset$ vrighed, det var L $\emptyset$ gn, sagde han i Talens Hede, hvad de havde angivet, var ikke gavnligt, det var endogsaa skadeligt, om De fik deres Ønsker opfyldt. Igaar købte jeg ved en anden Lille Jørls Sognebibliotek, ca. 200 Bind for - 25 Mark Courant, det skal et andet Sted hen, da Lorenzen har et Bibliothek der. Præsten havde skrevet et smukt Katalog over Bøgerne og lovpriste sin Vare som godt indbunden og nasten ny.

11. 6. 1866 (M.): Skriv mig Graaes Adresse! Det kunde don være, at Tilladelse til Privatskole kunde erholdes, men Vognsen har ved sin Utaalmodighed gjort sig umulig hertil, efter min Mening. Han var hos Borgmesteren og forlangte sin Pension, men kunde ikke tale Tysk. Borgmesteren ytrede da, at han ikke havde 
noget imod en dansk Priratskole, men Læreren maatte i det mindste taalelig kunne forstaaeliggore sig paa Tysk ... Hvad vil Tiden bringe? Preusserne kaster $\emptyset$ sterrigerne ud af Holsten paa en høflig Maade. Er Krigen nu der? jeg tror det ikke endnu.

15. 6. 1866: Forresten kommer vel Krigen. Preusserne er i Dag rykket ind i Hannover. Her kommer Tropper fra Syd, Rhinlandere og Westfælinger, de siger, de vil ikke løsne et Skud, de løber straks over osv. ... Som man saar, høster man!

18. 6. 1866 (M.): Det er dog ellers yderst sære Tider vi lever i; hvad de fører til og hvor de fører os hen, er ikke let at sige. Imidlertid synes mig dog, som om Sløret, der har hvilet saa længe over det hemmelige Maskineri, hæver sig en Smule. Det er underlige Ting, der foregaar i Tyskland, de kan ikke forklares, uden at Napoleon sidder bagved Preussen. Dette antaget, kan jeg omtrent forklare mig det ræsentlige af det skete. Preussen spiller Italien i Nordtyskland, Bismarck Cavour, men paa hans egen Maade, alt med Napoleons Tilladelse. Alt dette forhindrer ikke, af vi kommer tilbage, efter Nationalitetsprincipet, naturligvis. Dette har i de sidste Dage fra alle Sider bekræftet sig for mig i den Grad, at jeg tror fuldt og fast, at den endelige L $\varnothing$ sning vil blive saaledes. Vi maa se at stræbe hen til at stemme vore vildfarende Brфdre for os, se at vende Hjerterne til Danmark, og hvis Regeringen i København ved, at Sagen staar saaledes, er det Synd og Skade, at den ikke paa en eller anden Maade underretter os derom og giver os Midler $i$ Hande til at understøtte os med. At Preusserne ikke er ledige, men arbejder i den Retning, haade hemmeligt og aabenbart, ved jeg ganske vist, og at de er heldige sommesteder, ved jeg desværre ogsaa. Ledige er vi ikke, men hvis Løsenet kom derovre fra, under en nogenlunde bestemt Form, saa vilde der blive anderledes Liv og Bevægelse; men maaske er det for tidligt, og maaske ved Regeringen endnu ikke, hvad den vil; vi maa da gaa efter vore egne Indskydelser saa længe og trøste os ved, at vi handler efter bedste Overbevisning. Man taler om Session her, 40.000 skal udskrives, saa vil der blive Liv her, egentlig baade glæder jeg mig dertil og frygter derfor. 
Nogle kunde have godt deraf, andre var det slemt for; men saa haaber jeg, den danske Armee vilde faa en ordentlig Tilvækst.

30. 6. 1866: Wensien, Lærer ved Marie Pigeskole, ytrede ved Lejlighed om den danske Skole: »Denne Rede skulde helt udryddes «. Volquardts sagde i Skolen i Bov ved Visitatsen: $\gg$ Jeg vil med Jernhænder rive alt Dansk ud her «, hvortil en Bonde svarede, idet han holdt begge knyttede Næver op for Volquardts Næse: $\gg$ og vi vil holde paa Dansk med Jernnæver «. Amtmanden, som stod ved Siden af Volquardts, sagde derpaa beroligende til ham: »han er en forrykt Dansker, lad ham lobe! Vor Kirke er bleven rigtig oppyntet: Prædikestolen er bleven beslaaet med rødt Fløjl til 3 Rdl. Alen samt med Sølvfrynser. Alteret ligeledes og desuden med et Broderi, skal være ganske mageløst sinukt; det er broderet af danske Damer her. Knæleskammelen er gjort bredere og ny beslaaet med amerikansk Læder. Over det hele er der til Hverdags trukket et Tæppe for St $\varnothing v$ og Sol. Det hele har kostet ca. 100 Rdl., frivillig Gave. Nu er min kone kvik, men vi har haft en slem Vinter og et slemt Foraar. Børnene raske. Jens læser Latin og Historie hos Præsten. Kan De ikke finde mig et Sted derovre, hvor jeg kan faa ham frit i Skole? Skænk dette en tilfældig Tanke! Hans Fremtid ligger mi s paa Sinde; men end lever den Gamle af Dage. Præsteboligen hliver malet og gjort i Stand fra det $\phi$ verste til det nederste, og Præsten er sjæleglad ved den Bolig, jeg ligesaa ved min, der navnlig er rar for min svage Kone. Idag skriver jeg ogsaa til Biskoppen. Fik jeg ikke Brevet paa overordentlig Maade afsted, turde jeg ikke skrive, hvad jeg skriver, for man kan ikke tro Slyngler. Haabet er frejdigt, om Preusserne eller $\emptyset$ sterrigerne faar Bankene, det rører mit følende Hjerte ligemeget. For $\phi v$ vigt faar vi i denne Tid den ene L $\varnothing g n$ efter den anden per Telegraf. Preusserne er sanddrue Folk.

1. 7. 1866: Idag Kirken helt fuld, og det er den hver Søndag; dette er en stor Lykke og Glæde. I S $\phi$ ndags prædikede Carstens en hel lang højrøstet Sludder, den lille Jørgensen er ikke saadan Deklamator, men hvad der i hans Hjerte bor, det taler han, og 
han har af en ung Præst at være en hel Del Menneskekundskab, der i Prækenen kommer frem, rigtignok forenet med en Del grundtvigske Forunderligheder. For $\varnothing v$ rigt har jeg sagt til Pastor J $\varnothing$ rgensen, at han maa vige, saasnart De indtræffer. Mange herlige gamle og unge bekendte Ansigter har jeg den Fornøjelse at se i Kirken om S $\not$ ndagen. Gid De snart maatte komme at samle dem alle. Skolens Adsplittelse har sat ondt Blod imod Herr Peters, kan De tro, men han er jo Frækheden selv. Gengældelsen kommer dog. Et smukt Brysseler Tæppe ligger for Alteret, givet af Ølbrygger Schmidts Kone, Md. Jakobsen og Frk. Steen.

9. 7. $1866(M$.$) : Vi er ellers ved godt Mod, man lærer jo$ efterhaanden Taalmodighed, Haabet er godt. Hvilket Myrderi i Tyskland! Det ser ud til at blive værre endnu, med de Nadelgeværer! De kan tro, vi faar Sejersefterretninger at høre og se, men Danske og Tyske er alle enige om, at meget er L $\phi \mathrm{gn}$, og at Preussen til sidst faar Sm $\varnothing$; der er ikke Tanke om Sympati for Preusserne; man ser ligegyldig paa, at de $4-5$ preussiske Faner trækkes op, naar Sejren fejres. Det er ingen Kamp, vi f $\phi$ rer, ingen af vore er med.For mig maa man slaa det halve af Tyskland ihjel, ja det hele. Forleden var jeg $i$ en By, i en Familie, som ogsaa De kender. Konen siger: »Faer, vi skal have vort Dannebrog istand «. »Hvorfor? « \o, for jeg er rigtig bange for, at de skulde komme overbukkende paa os, og det var dog en Skam, om vi intet Flag havde at stikke ud saa\&. - De ser, vi tror paa Mirakler; nu, der er intet umuligt.

18. 7.1866 (M.): Hvad De sidst skrev om, er sat i Værk efter bedste Evne. Johannsen ${ }^{\text {ss }}$ ) rejste i Mandags til Slesvig, han er nu den eneste Rigtige til de Sager, og han var efter min Mening sær-

53) Senere Rigsdagsmand Gustav Johannsen, f $\varnothing \mathrm{dt} 1840$, tog 1861 Skolelærereksamen i København og var 1862-64 Lærer i Angel. Efter sin Afskedigelse der, bosatte han sig i Flensborg, f $\varnothing$ rst som Lærer og dernæst som Boghandler og Forsikringsagent. Han tog virksomt Del i Afstemningsarbejdet i 1866-67 og var i 1869 med til at oprette „Flensborg Avis $\alpha$. Om ham se Haandbog S. 577-79; nogle af hans Breve fra den Tid findes aftrykt i Sønderj. Aarbøger 1940, S. 196-243. 
deles heldig. Hos Peschke havde der om Søndagen været en Udsending fra Regeringen, fra Scheel-Plessen, og spurgt, om han liunde som Dansk eller som Fører for de Danske i Slesvig (nøje huskes Ordene ikke, men stærk dansk Politiker mentes der) siden give en Udsending (ogsaa om han vilde) Oplysninger om Stemningen blandt Folk. Han svarede ja for hans Bys Vedkommende. Saa spurgtes der videre, om han $i$ andre Byer vidste lignende Mænd. En Liste blev ham forelagt, som han godkendte, og lovede at skaffe flere Navne tilveje, naar han havde lidt Betænkningstid til Mandag, da Udsendingen vilde komme igen. Resultatet af denne Samtale vides ikke, da Johannsen maatte med Jernbanen, men Peschke, der før ikke kunde vide, hvortil disse Navne skulde bruges, men som nu ved Johannsen fik bedre $O_{p}$ lysninger, Peschke vilde se at pumpe Udsendingen. Den Egentlige var endnu ikke kommen, men naar han kommer, skal Esselbach og Peschke nok faa det at vide. Saavidt og ikke videre. Det er dog vist, hvad De skrev om. Nu Listen, hvis Navne alle er af det reneste Vand, og som vil iforveien blive underrettede, hvilket ikke kan skade.

Flensborg: Kolding, Plætner, Partsch, Johannsen selv.

Sønderborg: Pingel, Slagter Reimers, Graasten: Farver J $\phi r-$ gensen, Apotheker Henningsen. Collund: Kammerraad Schmidt.

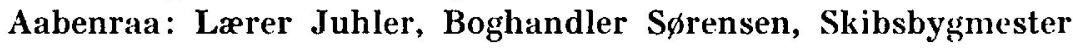
Igrgensen (?) huskes ikke rigtig. Tǿnder: Diemer. Hadersiev: Sabro, Knud Skov og en Forstmand, som ikke huskes. Listen kan jo blive st $\varnothing$ rre; jeg iler med at sige Dem, at vi har fat paa Finden og skal nok holde i. Johannsen er ubetalelig. Jeg formoder, at man ogsaa vender sig til et andet Parti, det vil vise sig. I de slesvigske Regjeringskredse taler man aabent om, at Danmark skal have Aabenraa-T $\phi$ nder, mærkeligt nok endda, at man under os saa meget.

19. 7. 1866: Skyttegilde i Marieskoven i Mandags, man marcherede ned til Skoven efter Mel. Længe var Nordens; ved Bordet udbragte Ed. Partsch Chr. IX's Skaal og den russiske Tronfølgers; Politiet spurgte ham strax om hans Navn. »Jeg hedder E. P. og bor der og der, ifald De vil mig noget *. (Alm. Latter). 
Danske Sange drillede Politiet hele Tiden, Skoven var fuld af Danske. Partsch kom siden for Politiet, der forb $\phi d$ ham at tage Del i Skytteforeningens Festmaaltid og Bal. Maatte blive hjemme. Fra Festen blev Forstanderskabet [Bestyrelson] hentet til I'olitimesteren, forhort og truet med strens Unders $\phi$ gelse samt event. Opløsning. -... I Harreslev var der Ringridning, Gensdarm tilstede, blev modtaget med: Dengang jeg drog osv. og »kom kun ind, og vær it reit, for vi er'et it«. Hele Natten Dans og Musik, Dansk og intet uden Dansk. Gensdarmen trak sig tilbage til Haven; der spadserede han hele Natten. - Fangedes saadant et Brev som det sidste, var De vel dækket, men jeg sgu fanget. Jeg tror aldrig Slyngler. P.

25. 7. 1866: Skillingssamlingen: Flere af de mest preussisk sindede, fine Damer har sat sig i Spidsen for en saadan. De gaar omkring to og to ligesom Apostlene fordum og beder i Guds Navn om en Skilling Courant ugentlig til de stakkels Saarede; det forstaar sig, det er af blot og bar Christenkærlighed, de gør det og ligeledes, at Giverne skal gøre det. De er ogsaa de fleste Steder heldige, da de er meget paatrængende, og man kan heller ikke godt sige Nej til saadanne fine, silkekliedle Damer, der desuden fortæller, at de endnu intet Steds har faaet Nej. Alle, selv de Fattigste i hele Gaden, har givet deres Skilling osv. Fru Bong-Schmidt selv gaar omkring og tigger. Hos mig var en ung Dame, der, da jeg kort sagde Nej, blev rød i Ansigtet, siden spurgte tre Gange, om jeg saa ikke vilde give. Fortalte hende, at hun de fleste Steder vilde være yderst uvelkommen, hvilket hun nok vidste; hun sagde, hun nok vidste, man hellere vilde give til de Danske. "Havde det endda varet til de Danske«, siger de næsten alle her $i$ Gaden, sagde hun, hun var nu ked af den Gang, men Fru Peters havde nødet hende dertil. Hos Torm var man ogsaa. »Hvor kan man tro, at jeg skulde give noget dertil? « sagde han. I Norden et Steds var Svaret: »Preusserkongen faar hver Dag mere Land, lad ham selv fǿde sine Saarede! « En Blikkenslager i Norden fik de endelig pint til at sige ja. Men saa kom Mutter, der havde staaet paa Lur i Køkkenet, og sagde: »Hvad, vil Du give Penge til det Røvertøj. Nej, det bliver der ikke 
noget af $\ll$. Tiggerne maatte gaa med uforrettet Sag. Hos en Mand i Syden var Fru Bong-Schmidt med en anden Dame. Samtalen f $\phi$ rtes paa Plattysk. Manden kunde ikke noksom forundre sig over, at de kom til ham og vilde have ham til at give til Preusserne, havde det endda været til de Danske. Saa kom de med deres Christenliebe og Plageri. »Hvem er De? « Ich bin Frau Bong-Schmidt «. »Wat for en Smidt? * »Bong-Sc.hmidt « »Naa, dat mut ik globen. He het froher Dänisch wesen, no is he prosisk. De Lüder, de köen alles, wat se schöllen. Naa is Se sin Fru, dann köen Se gaaen«. - Maatte gaa med en lang Næse. Hos Werner fik de et barsk Nej. Frøken Steen vidste ikke, at vi havde Saarede; hun viste dem to Dannebroge paa Væggen: „det er mine Farver, Preusserne gaar mig ikke an «. Hos Ølbrygger Schmidt fik de en voldsom Henfart; Md. Schmidt brugte sin hedste Mund: »Tror De, jeg vil give noget til de Folk, der har forfulgt mine Børn som Blodhunde? Jeg har syr Sønner, de skal alle komme til at kæmpe mod det R $\not$ vert $\emptyset \mathrm{j} ! \ll$ Hos Asmussen i Kompagniegade fik de: »Preusserne bringer os kun Uykker, de faar intet hos mig «. Holdt gav, men vedføjede, at det var af Christenkærlighed. Urmager Jakobsen bad man om en Skilling; lsan gav dem en rød [dansk] for at faa Sag med dem. Andre Skillinger kendte han ikke, da de sagde, de mente en Courantskilling. Siden fik de læst og påskrevet og gik tonhændet bort. Udbyttet har været slet, sk $\varnothing$ nt Peters gav 30 Mark Courant; naste Omgang vil det endnu blive slettere.

26. 7. 1866: Brændevinsbrænder Petersen i Nystaden gav Tiggerne en voldsom Henfart. Flere unge Folk var en S $\phi$ ndag en Sejltur med Dampskibet »Möwe«, der g $\phi r$ Lystture her paa Fjorden. Paa Hjemvejen var man lystig og sang i begge Kahytter. Man sang »Den tapre» osv., »Kong Chr.« osv., nogle begyndte at synge »Slesvig-Holsten \& osv., der overd $\varnothing$ vedes ved, at de Danske sang »Slesvig-Holstens falskc Sønner «. Ved Broen steg man i Land og gik hver til sit, kun mine tre Helte med Damer paa gik op ad Nygade, men her blev de forfulgte af tre sine Fyre med »Dänische Banditten « etc. Den ene fik saa Damerne at f $\phi r e$, medens de to andre traadte i Fægtestilling mod de tre, det blev 
en rigtig Spektakel. Klokken var 10, og Vægteren kom til. Han gav den ene af mine tre et Stфd i Siden, hvilket han tillige med et Blik nok forstod. Han bad da nu Vagteren om at sørge for, at de kunde gaa i Fred deres lovlige Vej. Vagteren forstod Sagen ret, peb, fik Hjælp, slæbte de tre i Hullet, skønt de paastod, de havde kongelig preussiske Bestallinger. Her laa de den Nat og betalte hver 5 Mark 4 Skilling Courant foruden to Skilling til Vægteren. De arresterede var $\gg Z$ Zollbeamten «. Det var en dansk Bedrift, der morer meget; Vægteren og de andre forstod hinanden uden at veksle et Ord. Men tys!

30. 7. 1866 (M.): Talte idag med en Mand fra Husby, som sagde: »Gud ved, at jeg har været tysk nok, men preussisk vil j‘g aldrig være«. »Tænker De saaledes alle derude i Angel? « »Ja«. --- Der er dog vist mange Preussere der nu?« _- »Ja vist, i det højeste er der 1 i hvert Sogn«. — \фil nær, for preussisk vil vi gar ud int vær«. _ »Da, vilde I nu vise Folk, at I hellere vilde være Danske end Preussere, saa skulde I ligesom i J $\varnothing \mathrm{rgensby}$ s $\phi g e$ om at faa et Par Timer Dansk ind $\mathrm{i}$ Skolen, det vilde ret ærgre Preusserne! Forresten kan I være ganske rolige; hvis Dansken kommer igen, faar I ikke mere Dansk, end I фnsker». Saa talte vi en hel Del, og jeg fik den Overbevisning, at Omvendelsen i Angel er paa gode Veje. Men kommer den gode Tid, da maa den nyttes fornuftigt: ingen tUberstürzung [Hastværk]; hellere holde tilbage end ægge til, naar Dansk skal indføres, dette kan nok drives paa en anden Bov. Provst Hansen vil være umulig her igen; der er flere, der absolut maa herned igen: Graae,Krog er selvskrevne; kun enkelte Skolelærere kan bruges: f. ex. Nissen med den skæve Mund ( Nej, det er dog Løgn; derimod Hansen, Eskris), gerrige Folk og Storsnuder er umulige, Broderen fra Solt ikke. Johannsen, Biskop Boesen var udmærket igen, mærkeligt nok, Amtmand Vedelsborg, Kammerherre Rosen, Herredsfoged Etatsraad Knudsen, Barfoed ubrugelig, Nielsen fra Hulvejen, den usleste Karl paa Jorden, ubrugelig, Wethje kunde bruges, Blauenfeldt blev modtaget med Glæde igen, ligesom Præsten i Bov, Præsterne Rørdam, Friis, Hansen-Gjelting, Broderen i Kværn derimod ikke, 
Herredsfoged Moltke fortræffelig, i det hele ma der nyt Udvalg til. At De, Mester Munck, kommer, er forudsat, saa lagger jeg mit Scepter ned.

1. 8. 1866: Rømer, Redaktør af Flensburger Zeitung, har været preussisk Agent i det nordlige Angel, men har gjort ren Fiasco. I det sydlige Angel, Kappel til Slien, drager Messmer omkring of samler skriftlige Stemmer for Preussen ... Jensen fra Ausager passede man op paa Hjemvejen [fra Skakbjerg], rev ham af Hesten og gav ham en banket Tr $\varnothing$ je. Øvrigheden her (r rigtig i Gang i Angel, der har varet flere Forsamlinger.

3. 8. 1866: Hvis De endnu skulde færdes dernede blandt Jyderne, saa benyt Tiden til at lære Jyden, at Tysk, som de desvierre holder saa meget al, er for dem noget af det farligste at give sig af med. De kan godt salge deres Svin og Stude uden Tysk, og jeg haaber ogsaa, komme i Himlen. Gud red, om det endnu er fint at være tysk dernede; har man endnu tyske Lærere og Lærerinder, saa gid de sad alle paa Bloksbjerg. Af mit Brev haaber jeg vil fremgaa, at vi er modne for en Afstemning, der sikkert vilde bringe et gunstigt Resultat.

4., 5., 6. 8. $1866\left(M . \circ g\left(G_{.}\right): \mathrm{Nu}\right.$ er for $\phi v r i g t$ 'Tiden til at virke, men det maa drives paa en meget rolig og fornuftig Maade, saa at Slesvig-Holstenerne ikke mærker, at vi trænger til og ønsker deres Hjælp. Vi skal kun se til fælles Hjælp som to naturlige Bundsforvandte at slutte .lliance imod Preusserne. Vi lover eller lader dog skinne igennem, at alt Had og al Hævn mellem os skal vige; derimod skal dette kastes paa alle Preussere, hvortil alle er villige, hvilket er herligt, da de preussisksindede i Virkeligheden er og har været de værste SlesvigHolstenere. Forøvrigt maa vi takke Preusserne for deres Wühlerier, de gør os i Virkeligheden en stor Tjeneste dermed, de

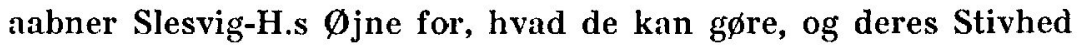
bliver derved vakt. Men vi maa som sagt gaa sindigt frem. Noget burde imidlertid de gode Afsatte derovre gøre, de burde knytte deres intime Baand ( $i$ det mindste) herovre og fortalle, at 
Hadet er forsvundet, at Dansk bliver siden kun indført efter Ønske af Befolkningen osv. Der kunde gøres meget Gavn paa denne Maade, men desværre, dette sker vist kun af faa. Om Stolthed, Dovenskab eller Døvhed er Skylden, maa Gud vide. Sorensen skildres jo som en Fatter med Natluen ned over Ørenc. Billedet passer fortræffeligt her. Vaagn op, I mange studerede og ulæerde $\mathrm{Hr}$. Sørensener, og trækker paa Strengenc, det turde cllers snart være for sildigt. Forøvingt tror jeg ikke mere paa Brevhemmeligheden, skønt jeg intet Bevis har paa Brud. Esmarch i Banken er nys bleven denuncieret i Bladet, det er morsomt, det træffer ham; man vil dermed true; det hjalper sku ellers ikke nu!

5. 8. 1866: Esmarch skal have sagt i Raadsvinkalderen til en preussisk Officer: at naar det kom til Afstemning, faldt Preusstrne igennem med Glans. Der kan man se Frygten male Satan paa Vaggen, og medens Preusserne wühler af alle Livsens Kriefter - hver preussisk Embedsmand og mange Agenter - , saa dækker de sig ved at hyle over dansk Agitation. Samme Spil bruges allevegne, ligesom da $\emptyset$ sterrig rustede og Preussen ikke. Smukke Tilstande!

6. 8. 1866: Man sqger at skramme Befolkningen med den store Krigsskat, der vil blive paalignet, enten man kommer til Danmark eller Tyskland, saaledes: »Kommer de ved at stemme til Preussen, saa bliver denne Skat lille, næsten for intet at regne, for den bliver lignet paa hele det store Preussen, derimod stemmer man for Danmark, saa bliver den ogsaa lignet, men Danmark er lille, paa denne Maade bereder man sig svære Byrder. [Klokken 10]: Der gaar det Rygte, at Johannsen er arresteret for politische Umtriebe [Agitation] i Angel. Gensdarmerne spørger ud efter og om ham, saa meget er vist. Har faaet ham advaret. Luften er svanger med uhyggelige Rygter. Forsigtighed udkræves.

18. 8. 1866 (G.): Liv er der nu i Tingen, men ikke nok endnu, da man jo svæver i Uvished i mange Stykker. Hvor langt skal 
der afstemmes? Kommer vi med? Naar skal der afstemmes og hvorledes? Alt dette gaar igennem vore Hoveder, vakker Uro, Bekymring, Haab, Harme og hvad alt det Tøjeri og Ut $\varnothing$ jeri hedder. Hvor jeg imidlertid har været, der haaber man at komme med, og der er man vis paa Stemmeflerhed for Danmark. Dettc er Regel helt ned i Syden. Om Enkeltheder i den Retning t $\varnothing$ r jeg ikke skrive. Der er allerede Tale om at hylde Preusserkongen. Det g $\phi \mathbf{r}$ jeg ikke, saa er jeg færdig, men efter min Regning lian dette ikke ske, f $\phi r$ Afstemningen er tilende, saa jeg er endnu fuldkommen rolig. Man kommer saa i værste Tilfælde til at gaa af uden Pension. Skulde Linjen komme Nord for os, vil dette vel blive Tilfaldet. Imidlertid venter jeg, at Danmark g $\phi \mathbf{r}$, hvad der er muligt, for at faa os med; men i sletteste Tilfælde maa Danmark tage, hvad det kan faa; vi kan lettere virke paa lidet end paa meget. Saa kommer vel den store Krig og bringer os vor rigtige Sydgranse. Nogle Trængselsaar, vel benyttede, kunde da maaske bringe de afskaarne Sydbocre til at sukke efter Egyptens Kødgryder og derved g $\varnothing$ re Nytte; dette staar nu i Herrens Haand. Ledig er jeg ikke og vil ikke være, saa længe Herren giver Kraft og Lejlighed. En Masse Dansk har jeg udbredt blandt Befolkningen ad 100 forskellige Veje, og jeg haaber, det slaar Rod, saasandt der er nordisk Liv og Kraft i Befolkningen her endnu. Politiet er ellers adressegal her. Enhver kan blive sat i Hullet for at udbrede Adresser til de Franskes Kejser. Modet, Hadet og Troen er stærke, Gud styrer vel alt til det bedste. Tjener til Efterretning, at P. har tillagt sig et stort Skæg, ${ }^{54}$ ) der er i bedste Væakst.

27. 8. $1866(G)$ : Stemningen er god og fuld af Haab; vi tror ikke, at Preussen tør spytte Frankrig og Europa i $\emptyset$ jnene, og kommer der Afstemning, saa er Resultatet sikkert lige til Ejdeı en. Lidt farligt med Politi og deslige er det ellers her, man maa

54) Hermed retledes Familietraditionen, hvorefter Tofte allerede $i$ 1864 besluttede, at hans Haar og Skæg ikke skulde klippes, f $\emptyset$ r S $\emptyset n-$ derjylland blev dansk igen. (Jfr. Pastor Knudsen, Bylderup, i solger Danske. Marts 1929; rigtigere udtrykker samme sig i sprogforeningens Almanak*1924, S. 59). 
ordentlig tage sig $\mathrm{i}$ agt. Imidlertid holdes ud, saalange muligt. Resultatet blive, hvad det vil med Hensyn til Sag og Person. At bolde den allersydligste Grænsefæestning, og forsvare den til sidste Mand, det har noget muntert ved sig, skønt og meget pinligt, det giver snart hvidt Haar. Man er jo pirret og opirret os hliver det dagligt, det virker paa Personen. Imidlertid er dog det gode Hum $\phi r$ ikke borte; selve Kampen har tit noget morsomt ved sig, som man suger Naring af. At ens Gerning ellers som f $\phi \mathbf{r}$ giver Tilfredsstillelse og Sjælenæring, er jo ikke muligt, det giver den nu ikke mig. Man lever først op, naar der ellers er noget at gøre, hvilket jo dog sker af og til. Sommetider sukker jeg efter Ro, sommetider efter noget at bestille, Skolen er i dette Tilfælde helt ude af Betragtningen. De forstaar vel nok, hvad jeg mener; men man skal leve her og tage virksomt Del i alt for at vide, hvordan Livet egentlig er under saadanne Forhold.

17. 9. 1866: Artikel 5 i Freden lover Tilbagegivelse af hvormeget? Hvornaar skal det ske? Sker det overhovedet? At en Forandring er nær forestaaende, det tror jeg, men om den er til det bedre, det maa Gud vide, det ser næppe ud dertil. En sørgelig Artikel i »Fæedrelandet tydede paa det værste. Nu, komme, hvad der komme vil, jeg er beredt og enig med mig selv. Til Preusserkongen gør jeg hverken Ed eller giver Haandslag; saa anser jeg min Rolle ved Skolen for udspillet, og glad i Sindet over dog $\mathrm{i}$ og ved Skolen at have leveret et uomstødeligt Bevis for Flensborgs Danskhed, skal jeg forlade min Plads, for med Familie at søge mit Brød, hvor Herren vil lade os finde det, men inderlig bedrøvet tillige, hvis jeg skulde nфdes til at forlade Kamppladsen, før Sejren er vunden; for den maa og skal vindes, om ogsaa mange $\emptyset$ jne maa lukkes, før det vil ske, hvilket man imidlertid ikke kan vide. Det staar dog tilsidst i Herrens Haand, og hans Time kan slaa, f $\varnothing \mathbf{r}$ vi ved det. At forlade Skolen skal ikke forvolde mig stor Sorg: Dette Aars Konfirmander er jo reddede, 37 i Tallet, og saa tæller Skolen kun en 80 til 90 Børn. Kan en lille Kaltringestreg imidlertid holde mig om end kun Dage eller Uger i min Stilling, saa skal der intet vare i Vejen fra min Side, men med Eden, som jeg aldrig vilde kunne holde, 
vil jeg ikke lege. Selv om jeg vilde aflægge den, saa føler jeg, at jeg vilde forarge hver eneste af mine Elever her, og f $\phi \mathbf{r}$ jeg skulde dette, vil jeg hellere tigge om Brødet til mig og mine. Saa slemt bliver det dog vel ikke; i Danmark er der dog Danske endnu, og til dem maa saa jeg med flere ty i det Haab, at de vil række os en hjælpsom Haand. Forøvrist er det ret mærkeligt, at jeg som den f $\phi$ rste ved Skolen ogsaa skal vare den sidste, og formodentlig komme aldeles bar bort. De har vel set, hvad jeg sidst sendte Graae, der kan De ellers se Vedkommendes Velvilje imod mig. 600 Rdl., omtrent mindre om Aaret, men det gaar og maa gaa; vi lever som Hunde og sparer, hvor vi kan, og er cndda inderlig glade, naar vi kan paa en eller anden Maade gavne. Skal jeg bort, kommer jeg vist en Tid over, f $\phi \mathbf{r}$ jeg tager Bestemmelse om Fremtiden. Saa mørk kan jeg se Fremtiden, det havde De vel næppe troet, og dog forsikrer jeg, jegs ser Fremtiden aldeles roligt og egentlig uden Bekymring i M $\phi d e$. Hver Dag har nok sin Plage, dette er mit naturlige Valgsprog. Om Deputationen er De vel underrettet. Den bestod af 47: fra Flensborg: Plietner [Frands], Hoegh, Hans Jensen (Glas-) (3 deputerede Borgere), Hans Jørgen Petersen, Kaptajn Dethlefsen. Den optraadte flot i Berlin ${ }^{53}$ ) og kom dertil uformodet, saa man var nær ved at give dem Foretræde, da man ikke vidste, hvad den f $\phi$ rte i sit Skjold. Imidlertid maatte den n $\emptyset$ jes med at overgive Adressen til en Legationssekretær, der lovede at forelæse Bismarck den, han vilde siden forelægge Kongen den. Skriftligt Svar skulde de faa i Hjemmet. Ordfører var Ahlmann fra Werthemine paa Als, Broder til Lieutnanten; han skilte sig godt ved Sagen. Preusserne her har gaaet om med en Annexionsadresse, der uagtet al anvendt Flid og Møje kun fik 117 Underskrifter. Plessen, til hvem den indsendtes til videre Besørgelse, sendte den tilbage hertil igen som alt for geringfügis [intetsigende] for en By paa 20.000 Indbyggere, og nu er Dr. Lorenzen i Bevagelse for at faa Tallet mangfoldiggiort.

55) 31. August 1866. Den omtalte Adresse, som var forsynet med 17.000 Underskrifter, indsendtes 11. November af Ahlmann til Deputeretkammeret i Berlin. Haandbog S. 624-25. 
22. 9. 1866 (M.): Nu har man et Cirkulære igang, det skal til Bismarck, det er en Tilslutning til de 47's Adresse; Gensdarmerne jager fra Gaard til Gaard derefter. I Christiansfeld trak man Folk ind fra Gaden og visiterede dem, saa nærgaaende er man. I Nustrup tog Gensdarmen efter halvanden Timers Jagt hele Kramkisten. Da han red bort dermed, begynäte man forfra. I Omegnen er der nu udlagt Militær for at trykke paa Stemningen. Fra Als er der afgaaet 7000 Underskrifter til Bismarck, Tilslutning til de 47's Adresse ...

1. 10.1866 (G.): Visitatsen gik glat, intet af det frygtede indtraf. Forresten havde jeg beregnet, at der skulde have varet Spektakel den Dag. Jeg gjorde mit bedste, for at det skulde ske; men man var Tilfredsheden selv. Provsten havde rendt Hornene af sig sidst, han sagde blot: $\gg \mathrm{Hr}$. Tofte, jeg kan ikke saa godt klare Dansk «. Jeg optog det som en Undskyldning og sagde: :Aa, det $g \varnothing r$ ingen Ting, Deres Højærværdighed, jeg forstaar nok Tysk«. Talte ikke et Muk Tysk, og Skolen prøvedes ikke en Gang i Tysk. Bong-Schmidt er ellers en ren B $\phi f f e l$, hvorfor jeg tænkte ved at træde ham paa Tæerne at kunne faa Spektakel. Lykkedes dog ikke ganske. Ikke talt med B.-S. f $\phi r$, kendte ham ellers nok. Satte mit dummeste Ansigt op og gik hen og spurgte Karlen, om han ikke vilde sige mig, hvem han var; jeg havde ilike den Fre at kende ham«. »Der Bürgermeister«, sagde han ganz verdutzt og satte sig, medens jeg begyndte at katekisere. Saa betænkte han sig imidlertid, stod op og vendte sig om til mig, sigende saa vredt som muligt: „forøvrigt er det ilke min Skyld, hvis De ikke kender mig«. Jeg morede mig og katekiserede videre. B.-S. talte til mig Dansk og Tysk. Ret store Sager foregaar der ikke for $\emptyset$ jeblikket, en Tilslutning til Adressen fra de $47 \mathrm{og}$ en Samling til Dagmar foregaar, eller skal foregaa snart. Kirken er stadig fuld, det er en stor Glæde; Skolen har nu kun 130, der er rejst nogle bort.

Efter at Hertugdømmerne ved kgl. Patent af 12. Januar 1867 (bekendtgjort den 24. s. M.) var bleven indlemmede i Preussen "g der forlangtes Edsaflaggelse af Embeds- og Tjenestemænd, 
bliver Toftes Stilling mere og mere tilspidset. Hans Duge som Leder af den danske Borgerskole er nu virkelig talte.

4. 3. 67: Idag har jeg indsendt følgende Erklæring: »Da mine Embedsindtregter i de sidstforl $\phi$ bne tre Aar aldeles uden min Skyld er blevne formindskede med ca. 1100 Mark Courant aarlight, og jeg med Familie desaarsag ikke kan leve deraf uden med hvert Aar at gaa mere og mere tilbage, og da der ingen Udsigter er til, at dette store Tab vil blive mig godtgjort eller mit Embede blive forbedret, trartimod, det skal om kort Tid nedlægges, saa tager jeg under disse Omstændigheder meget i Betæenkning at indgaa nye højtidelige Forpligtelser, og kan ikke give Mфde paa Onsdag den 6. d. M. for at aflægge Ed til H. Majestæet vor nye Konge, men beder derimod det h $\varnothing j e$ Kongelige Kirkevisitatorium udvirke mig Afsked fra dette mit Embede med Pension, og navnlig beder jeg højærværdige Hr. Provst Peters, Ridder etc., min Skoleinspekt $\phi r$, med sædvanlig Velvilje at anbefale mig til højere Vedkommende, at jeg ikke efter i 21 Aar at have virket som fastansat Lærer med Familie maa komme til at lide Nød.

Dette har jeg maattet indsende paa Dansk, da jeg i denne Sag ikke godt kan betro mig til en Oversætter.

Flensborg, den 4. Marts 1867.

Underdanigst

Hans M. Tofte,

Overlærer ved dansk Skole.

Det Høie Kongl. Kirkevisitatorium for Staden Flensborg.

De ser, jeg er gaaet udenom Knudepunktet, som Katten om den varme Grød; man maatte ikke gøre dem det umuligt at give mig Pension, ligesom heller ikke at gøre en selv det umuligt at leve og virke her. Slagteren, haaber jeg, vil vel nok føle, der er noget ironisk deri til ham. Hvad saa? Suspension straks, venter jeg; derpaa Afsættelse. Muligt vil man gaa paa Akkord med mig, og jeg skal da være villig til at overtage de $80 \mathrm{~B} \phi \mathrm{rn}$, som nu hliver Resten som Privatanstalt. At saadant kunne komme paa Tale, har jeg iøvrigt ikke Grund til at tro, lige saa lidt som at 
man vil give mig Pension. Man faar se. Tak for Deres venlige Indbydelse og for saa meget andet! Om kort Tid venter jeg at se Dem frisk og rask med Familie i Vedbak (enten som suspenderet eller afsat Skolemester) og bringe Dem en umaadelig Mangde Hilsener og Smaahistorier og Træk herfra. N. B. Om De forstaar at pumpe mig rigtigt. Hvem der g $\phi \mathrm{r}$ Eden, vil jeg ikke nu tale om, Aviserne vil bringe det; formentlig er jeg den eneste, der nagter. En usædvanlig velsignet Ro er indtraadt efter Ahlmanns Valg; man samler Kraft til et nyt Slag.»

7. 3. 1867 (G.): Igaar blev Eden aflagt af alle Præster, af J $\phi$ rgensen paa Dansk, og af 23 Lærere. Den 24. manglede, han havde som bekendt skrevet til Visitatoriet, at han ikke vilde; han sidder endnu urørt. Peters viste ham den store Venlighed at komme personligt hen i Skolen til ham den 5te og tale med ham om den Sag. Mdm. Tofte saa ham komme op af Bager Ebbesens Gaard, gaa forbi Skolen henimod Bellevue, venc̈e om igen og saa komme ind i Skolen, hvor der netop holdtes Sangtime: „Nu De synger? « $\gg \mathrm{Ja}$, jeg er netop færdig, skal jeg synge en ny? «. Intet Svar. Jeg kunde ikke godt komme til Orde, begyndte saa: »Var igaar saa fri at skrive til Visitatoriet «. »Det var netop derom han vilde tale«. - - Er det Deres Mening, Herr T.? « $\mathrm{J}_{a}$, naturligvis $\ll$. »Hvor kan De vente at faa Pension? - $»$ Netop fordi De er Provst og kan forhjælpe mig dertil«. - »Det er jeg bange for, jeg ikke kan «. — $\gg$ De vil da g $\phi r e$ alt, hvad der staar i Deres Magt for at skaffe mig den; jeg er glad over, det sker, da De er Provst, saa vil der da idetmindste ske, hvad ske kan for mig. Af den Grund har jeg netop anført disse Grunde, og blandet Deres Navn i Sagen, og ikke anfort andre Grunde, der maaske liunde saare paa andre Steder«. »Betænk Dem, hvad De gør, De har Familie! « »eg vil ikke mere være Syndebuk for den danske Menighed «. - - Den har De ingen Forpligtelser mod mere, De har holdt godt ud saa længe, og der er mange, der skylder Dem Forbindtligheder derfor «. - - Maa jeg spфrge: Bor de her i Byen? — Forlegen: »Graae og flere maa jo se at hjælpe Dem «. - »De har nok i deres egen Del «. — »Naar De ikke g $\phi \mathrm{r}$ Ed her, maa de se at hjælpe Dem derovre ${ }^{-}$— $\gg$ Min Stilling er saa ekstra- 
ordinar, at ingen i hele Hertugdommet kan sammenlignes dermed, og Regeringen maa give mig Pension«. _ $\gg$ Betank Dem, Herr T., med denne Pension til Embedet, vil dette ikke vare saa ringe $\ll$. — $\gg$ Har betænkt mig og er glad over, at De har med Sagen at gøre, saa vil den faa et saa godt Udfald som muligt 'T'. muntert: Jeg havde ventet Suspension i Dag os Afsxttelse imorgen $\ll$. - $\$ N e j$, det har ingen Hast«. — Venter, at Deres Højaervardighed g $\varnothing \mathrm{r}$, hvad De kan, har talt aabent og arligt med Dem derom«. - P.: »Jeg taler lige saa aabent og rerligt med Dem, som De med mig«. - \Derom tvivler jeg ingenlunde«. »Jeg har talt med Dem som Mand, betænk Dem nu ogsaa som Mand; Deres Skrivelse gør jeg ikke Brug af, før jeg ser, De ikke kommer «. - 'Tak for Deres Venlighed, Herr Provsl «. (Har siden intet hørt til Sagen). Saa forlegen og vred ud, den Provst, og var aabenbart ikke i sit Es.

Kun faa Dage efter modtog Tofte officiel Meddelelse om sin Afsked uden Pension $i$ en Skrivelse, som her gengives $i$ dansk Oversattelse:

Nedenstaaende Regeringsskrivelse, dat. 16. d. M., der i Udtog er meddelt Skolekollegiet af Kirkevisitatoriet:

¿ en Ansøgning til Regeringen har Larer Tofte ved den danske Skole i Flensborg erklæret, at han tager i Betænkning at aflagge den foreskrevne Tjenestecd til H. M. Kongen, og tillige bedt om Afsked med Pension.

Da den i Allerhøjeste Forordning al 22. Jan. d. A. foreskrevne - navnlig ogsaa af de offentlig ansatte Larere forlangte - Aflreggelse af Tjenesteeden ma anses som en ueftergivelig Forudsatning for Bibeholdelse af et betroet Embede, maa hans Forbliven i Embedet regnes for at vare umuligt, og afskediges Vedkommende derfor under Dags Dato fra sit Embede som Larer ved den danske Skole i Flensborg.

Men da fremdeles hans Edsnagtelse indbefatter en Frasigelse af en Statstjeners Pligter saavelsom hans Rettigheder, kan Regeringen ingen Grund finde til at bevilge Laerer Tofte hans Ansøgning om Pension «,

skal vi efter Paalæg fra K. V. meddele Herr Laerer Tofte til 
Efterretning med den Anmodning nu at indstille Deres Virksomhed som Larer ved den danske Skole og underrette os om, til hvilket Tidspunkt De vil kunne romme den for Tiden af Dem benyttede Tjenestebolig. -

Flensborg, den 21. marts 1867.

Skolekollegiet for St. Marize Sogn.

Bong-Schmidt. Peters.

Brinkmann. H. Henningsen. A. C. Jensen. Carstens.

P. F. Petersen. Joh. Hansen.«

Efter sin Afskedigelse virkede Tofte nogle Aar for Bogsagen og Landboforeningen $i$ Mellemslesvig, indtil han $i 1869$ overtog Landbrugs- og Højskolen Aagaard $i$ Oversø Sogn. 1889 matte den lukkes og 1892 sielges. Tofte flyttede derefier over til sin cneste Datter Valborg i Skaarup pan Fyn, hvor han d $\phi$ de som en blind Olding den 3. Januar 1917, 92 Aar gammel.

Den danske Borgerskole i Flensborg bestod endnu til 1. Januar 1871 under Larer $N$ is se ns Ledelse. Da ophroedes den helt, og tilbage var kun de danske Privatskoler i Flensborg. 